\title{
Article \\ Nitrogen Immobilisation and Microbial Biomass Build-Up Induced by Miscanthus $x$ giganteus L. Based Fertilisers
}

\author{
Michael Stotter ${ }^{1,2, *}$, Florian Wichern ${ }^{3}\left[{ }^{(0}\right.$, Ralf Pude ${ }^{2,4} \oplus^{-}$and Martin Hamer ${ }^{1, *}$ \\ 1 International Center for Sustainable Development, Bonn-Rhein-Sieg University of Applied Sciences, \\ 53757 Sankt Augustin, Germany \\ 2 Institute of Crop Science and Resource Conversation-Renewable Resources, University of Bonn, \\ 53359 Rheinbach, Germany; r.pude@uni-bonn.de \\ 3 Faculty of Life Sciences, Rhine-Waal University of Applied Sciences, 47533 Kleve, Germany; \\ Florian.Wichern@hochschule-rhein-waal.de \\ 4 Field Laboratory Campus Klein-Altendorf, University of Bonn, 53359 Rheinbach, Germany \\ * Correspondence: michael.stotter@h-brs.de (M.S.); martin.hamer@h-brs.de (M.H.)
}

Citation: Stotter, M.; Wichern, F.;

Pude, R.; Hamer, M. Nitrogen

Immobilisation and Microbial

Biomass Build-Up Induced by Miscanthus $x$ giganteus L. Based Fertilisers. Agronomy 2021, 11, 1386 https://doi.org/10.3390/

agronomy 11071386

Academic Editor: John Hammond

Received: 27 May 2021

Accepted: 7 July 2021

Published: 9 July 2021

Publisher's Note: MDPI stays neutral with regard to jurisdictional claims in published maps and institutional affiliations.

Copyright: (c) 2021 by the authors. Licensee MDPI, Basel, Switzerland. This article is an open access article distributed under the terms and conditions of the Creative Commons Attribution (CC BY) license (https:/ / creativecommons.org/licenses/by/ $4.0 /)$.

\begin{abstract}
Cultivation of Miscanthus x giganteus L. (Mis) with annual harvest of biomass could provide an additional $\mathrm{C}$ source for farmers. To test the potential of Mis- $\mathrm{C}$ for immobilizing inorganic $\mathrm{N}$ from slurry or manure and as a $\mathrm{C}$ source for soil organic matter build-up in comparison to wheat (Triticum aestivum L.) straw (WS), a greenhouse experiment was performed. Pot experiments with ryegrass (Lolium perenne L.) were set up to investigate the $\mathrm{N}$ dynamics of two organic fertilisers based on $\mathrm{Mis}$ at Campus Klein-Altendorf, Germany. The two fertilisers, a mixture of cattle slurry and Mis as well as cattle manure from Mis-bedding material resulted in a slightly higher N immobilisation. Especially at the 1st and 2nd harvest, they were partly significantly different compared with the WS treatments. The fertilisers based on Mis resulted in a slightly higher microbial biomass $C$ and microbial biomass $\mathrm{N}$ and thus can be identified as an additional $\mathrm{C}$ source to prevent nitrogen losses and for the build-up of soil organic matter (SOM) in the long-term.
\end{abstract}

Keywords: Miscanthus $x$ giganteus L.; organic $\mathrm{N}$ fertiliser; $\mathrm{N}$ immobilisation; $\mathrm{C}$ source; microbial biomass $\mathrm{C}$; microbial biomass $\mathrm{N}$; soil organic matter; $\mathrm{C}$ sequestration

\section{Introduction}

Technological developments, as well as economic conditions (agricultural subsidies, world market trade), have reduced the production costs in agriculture in the last decades. This has changed production methods resulting in nutrient access and pollution of the environment, especially in areas with high livestock density and slurry application and that, ultimately, threaten the long-term stability of agricultural production [1,2].

Inadequate soil management in arable farming can lead to soil degradation with negative effects on crop production being compensated by, for example, increased fertilisation; but more intensive treatments often lead to negative effects on the environment [3,4]. Along with agricultural intensification, increased nitrogen $(\mathrm{N})$ use resulted in lower $\mathrm{N}$ use efficiency (NUE) [5,6], to an accumulation of $\mathrm{N}$ in soil and to nitrate leaching into ground and surface waters, resulting in eutrophication. Furthermore, the risk of $\mathrm{NH}_{3}$ emissions with toxic effects on the respiratory system of mammals and humans and $\mathrm{N}_{2} \mathrm{O}$ emissions, which is a potent greenhouse gas, increased with enhanced $\mathrm{N}$ inputs $[7,8]$.

In addition, changed production practices, like the replacement of cereals with root crops and fodder crops with a lower $\mathrm{C} / \mathrm{N}$ ratio [9] and past land use changes by conversion of grassland to cropland [10-13] all led to a decrease in soil organic carbon (SOC) in many cases. Climate change with rising temperatures increases the decomposition of organic matter further and results in SOC losses [14]. Therefore, it is essential to use organic fertilisers and other $\mathrm{C}$ sources in a way that retains $\mathrm{N}$ and $\mathrm{C}$ in the crop-livestock-soil system 
and stops further SOC reduction or promotes SOC build-up. Thereby, soil microorganisms have a key function because they regulate essential $\mathrm{C}$ and $\mathrm{N}$ turnover processes in the soil.

Nutrient mobilization processes are often induced by microbial enzymatic activity, which is like nutrient immobilisation related to the soil microbial biomass (MB) $[15,16]$. The MB, which is dominated by fungi and bacteria [17], fulfils important functions in the soil. Anabolic processes lead to the incorporation of nutrients into biological structures and catabolic processes lead to mineralization of organic $\mathrm{N}_{\text {to }} \mathrm{NH}_{4}{ }^{+}$and of organic carbon (C) to $\mathrm{CO}_{2}$ [18]. Thereby, the catabolic turnover rate can result in up to $225 \mathrm{~kg} N$ released as inorganic $\mathrm{N}$ per hectare and year [19].

When organic fertilisers are applied, not all of the $\mathrm{N}$ supplied becomes available to plants in the year of application. Some organic $\mathrm{N}$ remains in the soil and only slowly releases inorganic $\mathrm{N}$ through microbial mineralisation processes in the months and years after application [20-22]. If this is insufficiently taken into account or is underestimated and if it does not occur simultaneously with the $\mathrm{N}$ demand of the plants, losses in the form of reactive $\mathrm{N}$ compounds to aquatic or terrestrial ecosystems may occur. These tend to increase when the SOC content decreases $[1,2,6,23]$. SOC is directly related to soil fertility and provides an essential function as both, source and sink for $\mathrm{C}$, mitigating climate change [24-27]. Changes in the SOC content, depending on C-input, are detectable not before several years [28], whereas changes in MB indicate long term changes of SOC [29] because SOC consists largely of cells and cell fragments of dead microorganisms, the microbial necromass $[30,31]$.

Microbial biomass N (MBN) and microbial biomass C (MBC) are closely correlated with each other $[18,19]$. In $\mathrm{C}$-limiting agricultural systems with high $\mathrm{N}$ inputs, $\mathrm{C}$ tends to be the most limiting factor for microbial growth [32]. Chen et al. (2014) [33] identified the incorporation of crop residues as an option to enhance $\mathrm{C} / \mathrm{N}$ ratios to reduce $\mathrm{N}$ leaching, but also describe that the $\mathrm{C} / \mathrm{N}$ ratio of incorporated substrates does not always predict $\mathrm{N}$ dynamics. Rather, soil properties and the biochemical composition of the substrate, especially the holocellulose/lignin ratio, are essential to $\mathrm{N}$ dynamics [33-36].

It is well known that keeping and incorporating cereal straw stimulates anabolic processes and consequently reduces $\mathrm{N}$ losses, as well as it contributes to SOC content [37-40]. However, these effects, driven by MBC turnover rates, are limited by the annual $C$ input [41]. A C-export in the form of straw selling and/or high organic $\mathrm{N}$ input with low $\mathrm{C} / \mathrm{N}$ ratio promotes high $\mathrm{N}$ mineralization. If this occurs in the period following harvest of the main crop and if it exceeds the $\mathrm{N}$ demand of the following crop, the risk of $\mathrm{N}$ losses increases [42]. Considering that microbial $\mathrm{N}$ immobilisation is basically related to $\mathrm{C}$ input (assuming sufficient supply of N, P, S, etc.) [33,41,43-46], especially in agricultural regions with high organic $\mathrm{N}$ input and where cereal straw is being limited, $\mathrm{N}$ immobilisation should be facilitated by other $C$ sources.

Here, Miscanthus $x$ giganteus L. can be a solution as multi-purpose crop which performs essential ecosystem services during cultivation. Furthermore, it can be cultivated as a lowinput crop because of low fertilizer demand and no weed control [47] and is certified as a greening crop in Germany (a crop subsidised for its ecological value) [48]. Miscanthus can be used as feedstock in anaerobic digestion [49,50], as growing media in soilless cultivation [51], as an additive for packaging industry or as construction material [52] and can be cascaded to livestock farms in the form of bedding material [53]. Nevertheless, the question is whether Miscanthus can be applied as a straw substitute, where cereal straw is lacking (e.g., because cereal straw is exported), for microbial $\mathrm{N}$ immobilisation and SOC build-up.

Therefore, in a pot experiment with ryegrass, we tested the effects of two novel $\mathrm{N}$-containing and C-rich organic farm manures on $\mathrm{N}$ immobilisation as well as on soil microbial biomass. One was a mixture of cattle slurry with Miscanthus and the other was a cattle manure based on Miscanthus bedding material. 
In this context, our hypotheses were (i) Miscanthus is as good as wheat straw in immobilising additional inorganic $\mathrm{N}$ from mineralisation of slurry or manure; (ii) Microbial biomass make use of Miscanthus as $\mathrm{C}$ source for biomass build-up and thus $\mathrm{C}$ sequestration.

\section{Materials and Methods}

\subsection{Site Description}

In 2018, two pot experiments and in 2019, a third one, were set up in the greenhouse at Campus Klein-Altendorf (University of Bonn, Rheinbach, Germany). The third one was performed with a different composition of slurry and manure than those, used for the first two (see below for details).

The set-up was chosen to compare the $\mathrm{N}$ dynamics of two organic fertilisers based on Miscanthus $x$ giganteus L. (Mis) in an arable soil of a conventionally used agricultural site in the Rhine region.

This site from where soil samples were taken, has never received any organic fertilisation before, but was converted from grassland to arable in the year 2013. Soil (GleyCambisol) was taken from the Ah horizon (silty clay; up to $30 \mathrm{~cm}$ depth) of a field (50 $36^{\prime} 3^{\prime \prime}$ $\mathrm{N}, 07^{\circ} 01^{\prime} 37^{\prime \prime} \mathrm{E}$; WGS 84) at Campus Klein-Altendorf, sieved to $<4 \mathrm{~mm}$ and thoroughly homogenized manually. Afterwards, the gravimetric water content and the water holding capacity of the soil were determined [54]. The soil texture was silty loam as determined by particle-size analysis according to DIN ISO 11277:2002-08 [55]. Basic soil properties like $\mathrm{pH}$ [56], $\mathrm{P}_{2} \mathrm{O}_{5}, \mathrm{~K}_{2} \mathrm{O}$ [57], $\mathrm{Mg}$ [58], B, Cu, Mn, Fe [59], SOM [60] and $\mathrm{N}_{\mathrm{t}}$ [61] are given in Table 1.

Table 1. Basic soil properties. Values show means and standard deviation $\left(n=5\right.$; for SOM, SOC, $\mathrm{N}_{\mathrm{t}}$, $\mathrm{C} / \mathrm{N}: n=6) ; \mathrm{SOM}=$ soil organic matter; $\mathrm{SOC}=$ soil organic carbon.

\begin{tabular}{|c|c|c|c|}
\hline $\mathrm{pH}\left(\mathrm{H}_{2} \mathrm{O}\right)$ & $P\left(\mathrm{mg} \mathrm{kg}^{-1}\right)$ & $\mathrm{K}\left(\mathrm{mg} \mathrm{kg}{ }^{-1}\right)$ & $\operatorname{Mg}\left(\mathrm{mg} \mathrm{kg}^{-1}\right)$ \\
\hline $6.3 \pm 0.06$ & $11.4 \pm 2.7$ & $10.4 \pm 1.6$ & $14 \pm 1.9$ \\
\hline$B\left(\mathrm{mg} \mathrm{kg}^{-1}\right)$ & $\mathrm{Cu}\left(\mathrm{mg} \mathrm{kg}^{-1}\right)$ & $\operatorname{Mn}\left(\mathrm{mg} \mathrm{kg}^{-1}\right)$ & $\mathrm{Fe}\left(\mathrm{mg} \mathrm{kg}^{-1}\right)$ \\
\hline $0.5 \pm 0.04$ & $6.3 \pm 0.5$ & $169.4 \pm 47.4$ & $196.3 \pm 18.6$ \\
\hline SOM (\%) & SOC (\%) & $\mathrm{N}_{\mathrm{t}}(\%)$ & C/N (ratio) \\
\hline $3.9 \pm 0.7$ & $2.3 \pm 0.4$ & $0.27 \pm 0.02$ & $8.5 \pm 1.2$ \\
\hline Clay $\left(g_{k g}^{-1}\right)$ & Silt $\left(\mathrm{g} \mathrm{kg}^{-1}\right)$ & Sand $\left(\mathrm{g} \mathrm{kg}^{-1}\right)$ & \\
\hline 229 & 597 & 173 & \\
\hline
\end{tabular}

The experiment aimed to stimulate microbial growth by adding an additional agricultural C source to immobilise inorganic $\mathrm{N}$ and enhance SOC in the soil. Therefore, the biomass of Mis grown on another field was used for two utilization pathways, mixed with Cattle Slurry (CS) or used as bedding material creating Cattle Manure (CM). The Mis biomass was harvested in April 2017 (exp. 1, 2) or April 2018 (exp. 3) respectively with a forage harvester (Krone Big X 480) with a set cutting length of $30 \mathrm{~mm}$. The Wheat Straw (WS; Triticum aestivum L.) biomass of the treatment CS-WS was broken up and baled by a Claas Quadrant 3200 FC big baler with a ROTO CUT front chopper and FineCut cutting unit and the WS biomass of the variety CM-WS was not chopped and cut. WS used for exp. 1 and 2 was from August 2018, WS used for exp. 3 was from August 2019.

In one pathway of Mis use, CS was mixed with Mis (Cattle Slurry mixed with Miscanthus = CS-Mis) and, as a complementary treatment, CS was mixed with WS (Cattle Slurry mixed with Wheat Straw = CS-WS) and both converted into spreadable substrates. This has the objective to bind odorous compounds of the cattle slurry (CS), to keep nutrients in the topsoil for a longer time against precipitation, to reduce gaseous $\mathrm{N}$ emissions and to slow down the nitrification. It also aims to achieve a slower and longer lasting $\mathrm{N}$ mineralization of the mixtures. 
For the determination of the best possible mixing ratio of both mixed treatments (CS-Mis, CS-WS) concerning maximum absorption of CS to Mis and of CS to WS biomass, different amounts of CS (from 1 to $10 \mathrm{~kg}$ of CS in steps of $0.5 \mathrm{~kg} C S$ ) were mixed with $1 \mathrm{~kg}$ of Mis or WS. As a result of this pre-test, a complete absorption (no excess liquid visible) of the liquid fraction of CS to Mis and WS, respectively, over seven days, was achieved at a ratio of $5 \mathrm{~kg}$ of CS to $1 \mathrm{~kg}$ of Mis and at a ratio of $8.5 \mathrm{~kg}$ of CS to $1 \mathrm{~kg}$ of WS. After mixing, the two mixture treatments were stored for five weeks on a manure slab and covered with a silage film to prevent precipitation intrusion and allow for $\mathrm{N}$ immobilisation.

The other option to use Mis on a farm was the use of Mis as bedding material in livestock. For this purpose, cattle were bedded with Mis (Cattle Manure from Miscanthus $=\mathrm{CM}-\mathrm{Mis}$ ) and, as a reference, cattle were bedded with WS (Cattle Manure from Wheat Straw $=$ CM-WS) according to standard farm practice and mucked out after about six weeks. As a reference treatment for the two mixtures, a pure CS was tested in the experiment. In addition, two further treatments were tested, this was a mineral $\mathrm{N}$-fertilisation (Urea Ammonium Nitrate solution = UAN) as well as a treatment without any $\mathrm{N}$ applied $($ No Nitrogen applied $=\mathrm{NoN})$. All abbreviations of the fertiliser products and fertiliser feedstocks are listed in Table 2.

Table 2. Abbreviation and description of the fertiliser products and fertiliser feedstocks (Mis, WS) evaluated in the greenhouse experiments.

\begin{tabular}{ll}
\hline Abbreviation & Fertiliser Description \\
\hline CS & Cattle Slurry \\
CS-Mis & Cattle Slurry with Miscanthus addition $(5 \mathrm{~kg}: 1 \mathrm{~kg})$ \\
CS-WS & Cattle Slurry with Wheat Straw addition $(8.5 \mathrm{~kg}: 1 \mathrm{~kg})$ \\
CM-Mis & Cattle Manure from Miscanthus shredded bedding \\
CM-WS & Cattle Manure from Wheat Straw bedding \\
UAN & Urea Ammonium Nitrate solution \\
NoN & No Nitrogen applied \\
Mis & Miscanthus-shredding \\
WS & Wheat Straw-shredding \\
\hline
\end{tabular}

The application rates of the tested treatments were $120 \mathrm{~kg} \mathrm{~N} \mathrm{ha}^{-1}$ (experiment 1 ) and $170 \mathrm{~kg} \mathrm{~N} \mathrm{ha}^{-1}$ (experiments 2 and 3). The nutrient content of the applied fertilisers (Tables 3 and 4) was determined by a certified laboratory following the requirements of the Fertiliser Ordinance 2017 of Germany [62].

Table 3. Nutrient contents of the used treatments for experiment $1\left(120 \mathrm{~kg}\right.$ total $\left.\mathrm{N} \mathrm{ha}^{-1}\right)$ and experiment $2(170 \mathrm{~kg}$ total $\left.\mathrm{N} \mathrm{ha}^{-1}\right),(\mathrm{CS}=$ Cattle Slurry, CS-Mis = Cattle Slurry-Miscanthus (5 kg to $1 \mathrm{~kg}$ ), CS-WS = Cattle Slurry-Wheat Straw (8.5 kg to $1 \mathrm{~kg}), \mathrm{CM}-\mathrm{Mis}=$ Cattle Manure from Miscanthus shredded bedding, CM-WS = Cattle Manure from Wheat Straw shredded bedding, UAN = Urea Ammonium Nitrate, Mis = Miscanthus-shredding, WS = Wheat Straw-shredding).

\begin{tabular}{|c|c|c|c|c|c|c|c|c|c|}
\hline Test Parameter & Unit & $\mathrm{CS}^{1}$ & CS-Mis ${ }^{2}$ & CS-WS $^{2}$ & $\mathrm{CM}^{-M i s^{2}}$ & CM-WS $^{2}$ & UAN $^{1}$ & Mis $^{2}$ & WS $^{2}$ \\
\hline Dry matter & $\%$ & 9.2 & 21.6 & 16.8 & 32.8 & 33.2 & - & 87.8 & 86.2 \\
\hline Organic matter & $\%$ & 6.7 & 19.1 & 14.2 & 26.9 & 22 & - & 85.2 & 79.2 \\
\hline Total N & $\mathrm{kg} \mathrm{m}^{-3} / \mathrm{kg} \mathrm{t}^{-1}$ & 4.0 & 3.8 & 4.2 & 7.4 & 12.4 & 358.4 & 1.7 & 6.3 \\
\hline $\mathrm{NH}_{4}^{+}-\mathrm{N}$ & $\mathrm{kg} \mathrm{m}^{-3} / \mathrm{kg} \mathrm{t}^{-1}$ & 1.8 & 1.2 & 1.3 & 0.2 & 0.1 & 89.6 & $<0.1$ & 0.2 \\
\hline $\mathrm{NH}_{4}-\mathrm{N}$ in total $\mathrm{N}$ & $\%$ & 45 & 32 & 31 & 3 & 1 & 50 & 5 & 3 \\
\hline $\mathrm{C} / \mathrm{N}$ & ratio & 10 & 29 & 20 & 21 & 10 & - & 288 & 73 \\
\hline
\end{tabular}


Table 4. Nutrient contents of the used treatments for experiment $3\left(170 \mathrm{~kg}\right.$ total $\left.\mathrm{N} \mathrm{ha}^{-1}\right),(\mathrm{CS}=$ Cattle Slurry, CS-Mis = Cattle Slurry-Miscanthus (5 kg to $1 \mathrm{~kg}$ ), CS-WS = Cattle Slurry-Wheat Straw (8.5 kg to $1 \mathrm{~kg}$ ), CM-Mis = Cattle Manure from Miscanthus shredded bedding, CM-WS = Cattle Manure from Wheat Straw shredded bedding, UAN = Urea Ammonium Nitrate, Mis = Miscanthus-shredding, WS = Wheat Straw-shredding).

\begin{tabular}{|c|c|c|c|c|c|c|c|c|c|}
\hline Test Parameter & Unit & $\mathrm{CS}^{1}$ & CS-Mis ${ }^{2}$ & CS-WS $^{2}$ & $\mathrm{CM}-\mathrm{Mis}^{2}$ & CM-WS $^{2}$ & UAN $^{1}$ & Mis $^{2}$ & WS $^{2}$ \\
\hline Dry matter & $\%$ & 8 & 20.7 & 16.5 & 25.4 & 15.5 & - & 90.1 & 90.9 \\
\hline Organic matter & $\%$ & 5.3 & 18.0 & 13.5 & 22.9 & 12.4 & - & 86.9 & 86.3 \\
\hline Total N & $\mathrm{kg} \mathrm{m}^{-3} / \mathrm{kg} \mathrm{t}^{-1}$ & 3.5 & 3.7 & 3.9 & 5.0 & 5.0 & 358.4 & 3.0 & 4.4 \\
\hline $\mathrm{NH}_{4}^{+}$ & $\mathrm{kg} \mathrm{m}^{-3} / \mathrm{kg} \mathrm{t}^{-1}$ & 2.1 & 1.5 & 1.3 & 1.4 & 1.8 & 89.6 & 0.2 & 0.2 \\
\hline $\mathrm{NH}_{4}-\mathrm{N}$ in total $\mathrm{N}$ & $\%$ & 60 & 41 & 33 & 28 & 36 & 50 & 7 & 5 \\
\hline $\mathrm{C} / \mathrm{N}$ & ratio & 9 & 28 & 20 & 27 & 15 & - & 166 & 115 \\
\hline
\end{tabular}

The tested treatments were mixed with $6.2 \mathrm{~kg}$ dry matter soil and with additional plant macro- and micronutrients applied in inorganic form as shown in Table 5. These nutrients were also applied after the second and fourth harvest to avoid nutrient deficiency effects other than N. The soil was then filled into Kick-Brauckmann pots (with closed drainage) and German ryegrass (Lolium perenne L., Valerio) was sown at a sowing rate of $0.15 \mathrm{~g}$ per pot (sowing rate of $40 \mathrm{~kg} \mathrm{ha}^{-1}$ ). Each of the three experiments was set up as a completely randomized block design with five replicates per treatment (35 pots per experiment, 105 pots for the three experiments). To ensure ideal growth conditions for plants and soil microorganisms, all pots were adjusted to 60 to $70 \%$ of the maximum water holding capacity (WHC) by applying distilled water regularly. For this, pots were weighed twice to thrice a week, depending on temperature conditions and then irrigated.

Table 5. Form of supply and amounts of macro- and micronutrients to each pot supplied at the start of the experiment, after the second and after the fourth grass harvest. Nitrogen was only supplied once via the test materials at the start of the experiment.

\begin{tabular}{ccc}
\hline Nutrient & Nutrient $\left(\mathbf{m g ~ p o t}^{-1}\right)$ & Form of Supply \\
\hline $\mathrm{N}$ & $188 / 266^{\mathrm{a}}$ & Organic $\mathrm{N}_{,} \mathrm{NH}_{4}^{+\mathrm{b}} \mathrm{K}_{2} \mathrm{HPO}_{4}$ \\
$\mathrm{P}$ & 220 & $\mathrm{~K}_{2} \mathrm{HPO}_{4}$ \\
$\mathrm{~K}$ & 1800 & $\mathrm{~K}_{2} \mathrm{SO}_{4}$ \\
$\mathrm{Mg}$ & 400 & $\mathrm{MgSO}_{4} \bullet 7 \mathrm{H}_{2} \mathrm{O}$ \\
$\mathrm{B}$ & 5 & $\mathrm{H}_{3} \mathrm{BO}_{3}$ \\
$\mathrm{Zn}$ & 20 & $\mathrm{ZnSO}_{4} \bullet 7 \mathrm{H}_{2} \mathrm{O}$ \\
\hline
\end{tabular}

${ }^{a}$ For experiment $1,188 \mathrm{mg} \mathrm{pot}^{-1}\left(120 \mathrm{~kg} \mathrm{ha}^{-1}\right)$ and for experiment 2 and 3, $266 \mathrm{mg} \mathrm{pot}^{-1}\left(170 \mathrm{~kg} \mathrm{ha}^{-1}\right)$ were supplied. ${ }^{\mathrm{b}}$ Tables 4 and 5 .

\subsection{Plant and Soil Analyses}

In each experiment, plants were cut six times with scissors to $0.03 \mathrm{~m}$ height. The thermal time (cumulative day degrees from 6 to 22 o'clock) and the day after sowing of the respective harvests is shown in Table 6.

Table 6. Thermal time and days after sowing of each harvest of the specific experiment (exp.).

\begin{tabular}{ccccccc}
\hline & \multicolumn{7}{c}{ Harvest Number } \\
& $\mathbf{1}$ & $\mathbf{2}$ & $\mathbf{3}$ & $\mathbf{4}$ & $\mathbf{5}$ & $\mathbf{6}$ \\
\hline Exp. & \multicolumn{7}{c}{ Thermal Time } \\
\hline 1 & $646 / 55$ & $931 / 75$ & $1286 / 102$ & $1808 / 137$ & $2455 / 173$ & $3138 / 209$ \\
2 & $640 / 47$ & $926 / 67$ & $1304 / 96$ & $1880 / 133$ & $2516 / 168$ & $3260 / 204$ \\
3 & $627 / 42$ & $855 / 56$ & $1310 / 84$ & $1935 / 118$ & $2751 / 155$ & $3418 / 188$ \\
\hline a cumulative day degrees $\left(6\right.$ to 22 o $^{\prime}$ clock) above $5{ }^{\circ} \mathrm{C}$.
\end{tabular}

${ }^{a}$ cumulative day degrees (6 to $22 o^{\prime}$ clock) above $5{ }^{\circ} \mathrm{C}$. 
The obtained biomass was dried to a constant weight at $60{ }^{\circ} \mathrm{C}$ to calculate the dry matter yield. The dried biomass was ground by using a disk mill (TS 250, Siebtechnik $\mathrm{GmbH}$, Mülheim an der Ruhr, Germany) and $6 \mathrm{mg} \pm 0.2 \mathrm{mg}$ of each ground sample was weighed into tin cartridges. The $\mathrm{C}$ and $\mathrm{N}$ concentrations of each harvest-biomass was analyzed by using an elemental analyzer (EA 3000 series, HEKAtech GmbH, Wegberg, Germany). Plant $\mathrm{N}$ uptake was calculated by using dry matter yield and N concentration. It was extrapolated to one hectare, assuming a soil bulk density of $1.32 \mathrm{~g} \mathrm{~cm}^{-3}$ (Ah horizon up to $30 \mathrm{~cm}$ depth).

At the end of the experiments, a soil aliquot of each pot was used to analyze inorganic $\mathrm{N}\left(\mathrm{N}_{\text {min }}=\mathrm{NH}_{4}{ }^{+}+\mathrm{NO}_{3}{ }^{-} ; \mathrm{NO}_{2}{ }^{-}\right.$was not detectable), soil microbial biomass $\mathrm{C}(\mathrm{MBC})$ and soil microbial biomass $\mathrm{N}$ (MBN). For this, soil samples were sieved at $2 \mathrm{~mm}$ and all visible roots were removed. For the analysis of inorganic N, $25 \mathrm{~g}$ of the field-fresh soil was weighed into PE bottles, mixed with $100 \mathrm{~cm}^{3}$ of $1 \% \mathrm{~K}_{2} \mathrm{SO}_{4}$ and placed on an overhead shaker at $22 \mathrm{rpm}$ for $60 \mathrm{~min}$. After shaking, all extracts were filtered (VWR 305; particle retention: 2-3 $\mathrm{mm}$ ). The first $10 \mathrm{~cm}^{3}$ of the filtrate were discarded to obtain the purest possible extract. The extract was filled into plastic cuvettes, then stored until further analysis at $-18^{\circ} \mathrm{C}$. The inorganic $\mathrm{N}$ content was determined with the AutoAnalyzer 3 from Bran + Luebbe GmbH Norderstedt, Germany.

MBC and MBN were analyzed by chloroform fumigation-extraction [63,64]. Therefore, two portions of $10 \mathrm{~g}$ of moist soil were weighed into PE bottles. One sample was for fumigation- and the other one for non-fumigation-extraction. The fumigation was carried out in a vacuum desiccator at $25^{\circ} \mathrm{C}$ using ethanol-free chloroform $\left(\mathrm{CHCl}_{3}\right)$ for $24 \mathrm{~h}$ in the dark. The fumigated and non-fumigated samples were then extracted with $40 \mathrm{~cm}^{3}$ of $0.5 \mathrm{M} \mathrm{K}_{2} \mathrm{SO}_{4}$ and placed on a horizontal shaker at $180 \mathrm{rpm}$ for $30 \mathrm{~min}$. After shaking, all extracts were filtered (VWR 305; particle retention: 2-3 $\mu \mathrm{m}$ ) and stored until analysis at $-18{ }^{\circ} \mathrm{C}$ to avoid microbial transformation processes. Just before starting the analyses, extracts were defrosted rapidly to room temperature. In all extracts, organic $C$ and total $\mathrm{N}$ were detected after combustion at $800^{\circ} \mathrm{C}$ by using a Multi N/C 2100S (Analytic Jena, Jena, Germany). MBC was calculated as the ratio of extractable $\mathrm{C}(\mathrm{EC})$ and $k_{\mathrm{EC}}$. EC is the difference between organic $C$ extracted from fumigated soils and non-fumigated soils, whereas $k_{\mathrm{EC}}$ is a coefficient with the value of 0.45 [65] and represents the fraction of microbial $C$ released in $24 \mathrm{~h}$ of fumigation. MBN gets calculated as the ratio of extractable $\mathrm{N}(\mathrm{EN})$ and $k_{\mathrm{EN}}$. EN is the difference in organic $\mathrm{N}$ extracted from fumigated soils and non-fumigated soils, where $k_{\mathrm{EN}}$ is a coefficient with the value of $0.54[32,63]$ and represents the fraction of microbial $\mathrm{N}$.

Plant N uptake, inorganic N, MBC and MBN were extrapolated to one hectare, assuming a soil bulk density of $1.32 \mathrm{~g} \mathrm{~cm}^{-3}$ (Ah horizon up to $30 \mathrm{~cm}$ depth). The amount of $\mathrm{N}$ mineralized from applied fertilisers was estimated by subtracting the sum of plant $\mathrm{N}$ uptake of NoN treatments from the $\mathrm{N}$ uptake of the fertilized ryegrass. The total inorganic $\mathrm{N}\left(\mathrm{N}_{\min }\right)$ value at the start and end of the test was included in the calculation by subtracting these differences from the $\mathrm{N}$ uptake of each treatment. This calculation does not take into account $\mathrm{N}$ losses in the form of ammonia and nitrous oxide. These are assumed to be minimal because the organic fertilisers were incorporated into the soil immediately and the soil moisture was around $60 \%$ WHC.

\subsection{Statistical Analyses}

Dry matter yields are shown as arithmetic means $(n=5)$. Nitrogen uptake was calculated on a pot basis by multiplying the dry matter plant yield by the respective $\mathrm{N}$ content of the biomass and by extrapolation to the amount of soil in the upper $30 \mathrm{~cm}$ of a hectare. Statistical analyses were performed using IBM SPSS Statistics 27. Normal distribution of data was tested using the Shapiro-Wilk test. Levene's test based on means was used to verify homogeneity of variances. To identify treatment differences between three treatments, a one-way analysis of variance (ANOVA), following by a post hoc Tukey's HSD (honest significance difference) test were used. To identify differences between two 
treatments, $t$-test was used. Tukey's HSD and $t$-test were performed separately for each experiment. When data were not normally distributed or no homogeneity of variance were detected, Welch test and Games-Howell test were used to identify differences for three or more treatments, Mann-Whitney-U test was used to identify differences between two treatments. $p$-values of 0.05 were used as threshold for significant interactions.

\section{Results}

\subsection{Plant N-Uptake}

The plant $\mathrm{N}$ uptake indicates clear differences in the $\mathrm{N}$ availability of the applied $\mathrm{N}$ fertilisers. Ryegrass fertilized with mineral N (UAN) showed the highest $\mathrm{N}$ uptake at the 1st harvest, but already at the 3rd harvest, no differences in $\mathrm{N}$ uptake was detected between the mineral treatment and the treatment without $\mathrm{N}$ addition (NoN). When ryegrass was fertilized with cattle slurry (CS), lower amounts of $\mathrm{N}$ were plant-available especially at the 1st harvest as compared to mineral fertilisation (Figure 1).

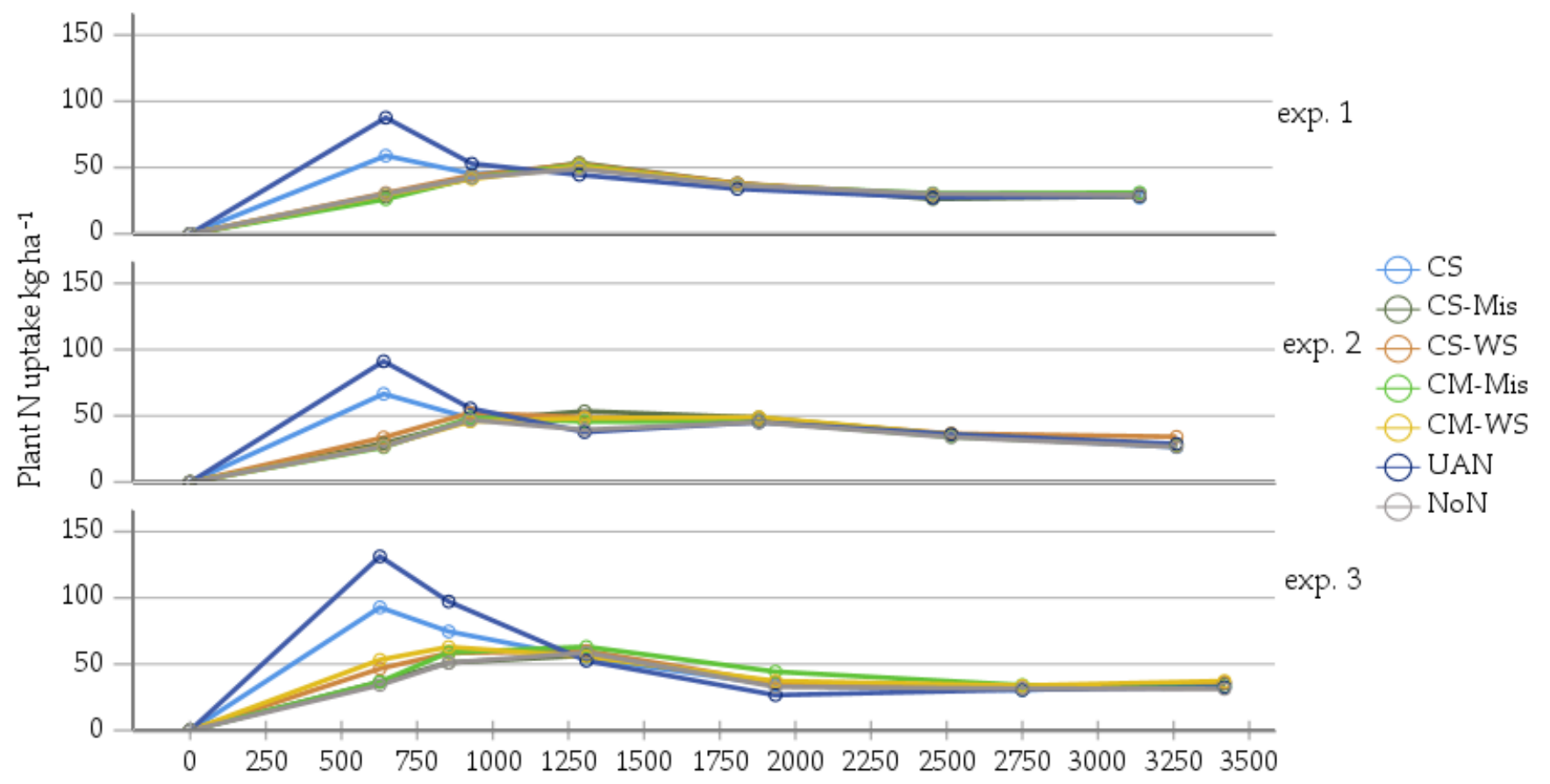

Thermal time (cumulative day degrees above $5^{\circ} \mathrm{C}$ )

Figure 1. Plant $\mathrm{N}$ uptake of ryegrass in relation to harvests (markings) and thermal time (cumulative day degrees above $5{ }^{\circ} \mathrm{C}$ ) in experiments 1, 2 and 3 for each treatment (CS = Cattle Slurry, CS-Mis = Cattle Slurry-Miscanthus (5 kg to $\left.1 \mathrm{~kg}\right)$, CS-WS = Cattle Slurry-Wheat Straw (8.5 kg to $1 \mathrm{~kg}$ ), CM-Mis = Cattle Manure from Miscanthus shredded bedding, CM-WS = Cattle Manure from Wheat Straw shredded bedding, UAN = Urea Ammonium Nitrate, NoN = No nitrogen applied).

The cumulated $\mathrm{N}$ uptake of ryegrass was significantly lower (7\% to $24 \%$ ) compared to pure CS when Mis or WS were mixed with CS and then applied as C-rich organic N fertiliser (Table 7). Compared to pure CS fertilisation, the addition of WS to CS induced a $7 \%$ to $17 \%$ reduction in plant $\mathrm{N}$ uptake and the addition of Mis induced a slightly stronger reduction with plant $\mathrm{N}$ uptake being reduced by $12 \%$ to $24 \%$ (Table 7 ). 
Table 7. Percentage of N uptake of the two mixtures (CS-Mis = Cattle Slurry-Miscanthus (5 kg to $1 \mathrm{~kg}$ ); CS-WS = Cattle Slurry-Wheat Straw $(8.5 \mathrm{~kg}$ to $1 \mathrm{~kg}))$ to $\mathrm{N}$ uptake of cattle slurry (CS), at the time of each harvest and cumulatively (cum). Listed for experiment (exp.) 1,2 and 3, respectively. Different letters within a column and within each experiment number show significant differences. One-way ANOVA; $p<0.05 ; \mathrm{ns}=$ not significant; $n=5$.

\begin{tabular}{|c|c|c|c|c|c|c|c|c|}
\hline & \multicolumn{8}{|c|}{ Harvest Number } \\
\hline & & 1 & 2 & 3 & 4 & 5 & 6 & cum \\
\hline Exp. & \multicolumn{3}{|l|}{ Treatment } & \multicolumn{5}{|c|}{ N Uptake [\% of CS] } \\
\hline \multirow{3}{*}{1} & CS & $100 \mathrm{a}$ & $100 \mathrm{a}$ & $100 \mathrm{~ns}$ & $100 \mathrm{~ns}$ & $100 \mathrm{~ns}$ & $100 \mathrm{~ns}$ & $100 \mathrm{a}$ \\
\hline & CS-Mis & $47 \mathrm{c}$ & $93 \mathrm{~b}$ & $107 \mathrm{~ns}$ & $101 \mathrm{~ns}$ & $95 \mathrm{~ns}$ & $101 \mathrm{~ns}$ & $87 \mathrm{~b}$ \\
\hline & CS-WS & $52 \mathrm{~b}$ & $97 \mathrm{ab}$ & $105 \mathrm{~ns}$ & $101 \mathrm{~ns}$ & $106 \mathrm{~ns}$ & $107 \mathrm{~ns}$ & $91 \mathrm{~b}$ \\
\hline \multirow{3}{*}{2} & CS & $100 \mathrm{a}$ & $100 \mathrm{ab}$ & $100 \mathrm{~ns}$ & $100 \mathrm{~ns}$ & $100 \mathrm{~ns}$ & $100 \mathrm{~ns}$ & $100 \mathrm{a}$ \\
\hline & CS-Mis & $44 \mathrm{c}$ & $96 \mathrm{~b}$ & $110 \mathrm{~ns}$ & $104 \mathrm{~ns}$ & $100 \mathrm{~ns}$ & $102 \mathrm{~ns}$ & $88 \mathrm{~b}$ \\
\hline & CS-WS & $51 \mathrm{~b}$ & $108 \mathrm{a}$ & $100 \mathrm{~ns}$ & $101 \mathrm{~ns}$ & $103 \mathrm{~ns}$ & $130 \mathrm{~ns}$ & $93 \mathrm{~b}$ \\
\hline \multirow{3}{*}{3} & CS & $100 \mathrm{a}$ & $100 \mathrm{a}$ & $100 \mathrm{~ns}$ & $100 \mathrm{~ns}$ & $100 \mathrm{~ns}$ & $100 \mathrm{~ns}$ & $100 \mathrm{a}$ \\
\hline & $\mathrm{CS}-\mathrm{Mis}$ & $39 \mathrm{~b}$ & $68 c$ & $104 \mathrm{~ns}$ & $104 \mathrm{~ns}$ & $102 \mathrm{~ns}$ & $99 \mathrm{~ns}$ & $76 \mathrm{~b}$ \\
\hline & CS-WS & $50 \mathrm{~b}$ & $78 \mathrm{~b}$ & $110 \mathrm{~ns}$ & $104 \mathrm{~ns}$ & $105 \mathrm{~ns}$ & $101 \mathrm{~ns}$ & $83 \mathrm{~b}$ \\
\hline
\end{tabular}

Especially in the period after application until the 1st harvest, the addition of Mis or WS to CS caused a significant reduction in plant $\mathrm{N}$ uptake. The addition of WS to CS significantly reduced plant $\mathrm{N}$ uptake by $50 \%$ compared to CS fertilisation only. The addition of Mis to CS caused an even greater reduction in plant $\mathrm{N}$ uptake (53\% to $61 \%$ ), which was statistically significant in exp. 1 and 2, compared to WS addition ( $48 \%$ to $50 \%$ ) (Table 7).

At the 2nd and 3rd harvest, $\mathrm{N}$ uptake of ryegrass, fertilized with mixtures of Mis or WS and CS slightly increased and the N uptake of ryegrass fertilized with pure CS slightly decreased, compared to the 1st harvest, however, only to a small extent (Figure 1). Therefore, in exp. 1 and 2, at the 2nd harvest, $\mathrm{N}$ uptake in ryegrass fertilized with CS-Mis is only $4 \%$ to $7 \%$ lower than that of the ryegrass fertilized with CS only.

Moreover, at the 2nd harvest, $\mathrm{N}$ uptake of ryegrass fertilized with CS-WS increased so that it was identical (exp. 1) or even higher than plant $\mathrm{N}$ uptake after pure CS fertilisation (exp. 2). In exp. 3, at the 2nd harvest, only 70\% (CS-Mis) to 80\% (CS-WS) of the $\mathrm{N}$ was taken up by plants compared to fertilisation with pure CS (Table 7). From the 3rd harvest until the end of the experiment (temperature sum of more than $3000^{\circ} \mathrm{C}$ ), the plant $\mathrm{N}$ uptake in ryegrass fertilized with the mixtures (CS-Mis, CS-WS) was in most cases higher than that after CS fertilisation only (Figure 1, Table 7).

Plant $\mathrm{N}$ uptake after CS-Mis fertilisation was only slightly lower than that after CS-WS application (Figure 1, Table 7).

When ryegrass was fertilized with the two cattle manure types, with Mis or WS, there was no significant difference in the cumulative plant $\mathrm{N}$ uptake, but rather in the dynamics of the relative $\mathrm{N}$ uptake (Table 8). Until the 1st harvest, the unfertilized ryegrass (NoN) took up the same amount of $\mathrm{N}$ as the ryegrass fertilized with $\mathrm{CM}-\mathrm{WS}$ or CM-Mis, respectively (Figure 1). In exp. 1 and 2, at the 2nd harvest, $\mathrm{N}$ uptake was slightly higher when CM-Mis was applied, but decreased in the further development mainly to a lower $\mathrm{N}$ uptake level compared to CM-WS (Table 8). Exp. 3 showed larger differences in the dynamics of plant $\mathrm{N}$ uptake between ryegrass fertilized with the two manure types. Here, ryegrass fertilized with CM-Mis took up more N (13\% to $19 \%)$ at the 3rd and especially at the 4th harvests, whereas uptake was lower at the 1st and 2nd harvest (Table 8). 
Table 8. Percentage of the new type of cattle manure from Miscanthus shredded bedding (CM-Mis) to $\mathrm{N}$ uptake of conventional cattle manure from wheat straw bedding (CM-WS), at the time of each harvest and cumulatively (cum). Listed for experiment (exp.) 1, 2 and 3, respectively. Different letters within a column and within each experiment number show significant differences between the two types of manure ( $p<0.05, t$-test); ns = not significant; $n=5$.

\begin{tabular}{ccccccccc}
\hline & & \multicolumn{7}{c}{ Harvest Number } \\
\cline { 3 - 9 } & & $\mathbf{1}$ & $\mathbf{2}$ & $\mathbf{3}$ & $\mathbf{4}$ & $\mathbf{5}$ & $\mathbf{6}$ & cum \\
\hline \multirow{2}{*}{ Exp. } & Treatment & \multicolumn{7}{c}{ N Uptake [\% of CM-WS] } \\
\hline \multirow{2}{*}{1} & CM-Mis & $88 \mathrm{~B}$ & $102 \mathrm{~ns}$ & $102 \mathrm{~ns}$ & $98 \mathrm{~ns}$ & $106 \mathrm{~ns}$ & $109 \mathrm{~ns}$ & $101 \mathrm{~ns}$ \\
& CM-WS & $100 \mathrm{~A}$ & $100 \mathrm{~ns}$ & $100 \mathrm{~ns}$ & $100 \mathrm{~ns}$ & $100 \mathrm{~ns}$ & $100 \mathrm{~ns}$ & $100 \mathrm{~ns}$ \\
\hline \multirow{2}{*}{2} & CM-Mis & $97 \mathrm{~ns}$ & $106 \mathrm{~ns}$ & $95 \mathrm{~ns}$ & $94 \mathrm{~ns}$ & $95 \mathrm{~ns}$ & $98 \mathrm{~ns}$ & $97 \mathrm{~ns}$ \\
& CM-WS & $100 \mathrm{~ns}$ & $100 \mathrm{~ns}$ & $100 \mathrm{~ns}$ & $100 \mathrm{~ns}$ & $100 \mathrm{~ns}$ & $100 \mathrm{~ns}$ & $100 \mathrm{~ns}$ \\
\multirow{2}{*}{3} & CM-Mis & $69 \mathrm{~B}$ & $93 \mathrm{~ns}$ & $113 \mathrm{~ns}$ & $119 \mathrm{~A}$ & $101 \mathrm{~ns}$ & $88 \mathrm{~B}$ & $96 \mathrm{~ns}$ \\
& CM-WS & $100 \mathrm{~A}$ & $100 \mathrm{~ns}$ & $100 \mathrm{~ns}$ & $100 \mathrm{~B}$ & $100 \mathrm{~ns}$ & $100 \mathrm{~A}$ & $100 \mathrm{~ns}$ \\
\hline
\end{tabular}

\subsection{Microbial Mineralisation-Immobilisation as Affected by Added Miscanthus Straw}

The fraction of mineralised $\mathrm{N}$ was significantly reduced after adding organic $\mathrm{C}$ in the form of Mis or WS to cattle slurry in each experiment (Figure 2A). Thereby, the addition of Mis resulted in a lower mineralized $\mathrm{N}$ fraction compared to the WS addition, in all 3 experiments (Figure 2A). In exp. 2 and 3, the difference was statistically significant. In exp. 1 and 3, Mis addition even resulted in no additional $\mathrm{N}$ mineralization compared to unfertilized ryegrass (Figure 2A). In exp. 2, 13\% of the fertilized N from CS-Mis became plant available as inorganic $\mathrm{N}$. In contrast, more $\mathrm{N}$ was mineralized in CS-WS, which was $6 \%$ in exp. 1, 20\% in exp. 2 and $17 \%$ in exp. 3 . These differences result mainly from the different $\mathrm{N}$ release patterns after application to the soil, as shown by plant $\mathrm{N}$ uptake especially at the 1st harvest (Table 7). This reduced N uptake, as a result of Mis or WS addition to CS, may indicate lower $\mathrm{N}$ release from CS through mineralization or increased $\mathrm{N}$ immobilisation by soil microorganisms facilitated by easily available $\mathrm{C}$ added with CS-Mis or CS-WS (Table 7).

The microbial biomass $\mathrm{C}(\mathrm{MBC})$ and $\mathrm{N}(\mathrm{MBN})$ were both not significantly affected by adding $\mathrm{C}$ to CS either as Mis or WS (Figures 3 and 4). However, the mean of MBC was slightly higher in CS-Mis compared to CS-WS, moderately in all experiments (Figure 3A). The MBN indicated the same tendency of increasing after addition of CS-Mis compared to fertilisation with CS-WS (Figure 4A). Thus, the lower N mineralization of CS-Mis compared to CS-WS (Table 7, Figure 2A) is generally reflected in a slightly higher microbial biomass (Figures $3 \mathrm{~A}$ and $4 \mathrm{~A}$ ). In CS-Mis, MBN was $23 \mathrm{~kg} \mathrm{ha}^{-1}$ to $60 \mathrm{~kg} \mathrm{ha}^{-1}$ higher and in CS-WS, MBN was $19 \mathrm{~kg} \mathrm{ha}^{-1}$ to $51 \mathrm{~kg} \mathrm{ha}^{-1}$ higher than MBN in the non-fertilised treatment (Table 9). Apparently, when Mis was used for mixing with CS, soil microorganisms were able to immobilize more $\mathrm{N}$ as compared to WS.

Table 9. $\mathrm{N}$ immobilisation calculated of MBN of fertilised treatments and non-fertilised treatment (CS = Cattle Slurry, CS-Mis = Cattle Slurry-Miscanthus (5 kg to $1 \mathrm{~kg}$ ), CS-WS = Cattle Slurry-Wheat Straw $(8.5 \mathrm{~kg}$ to $1 \mathrm{~kg}$ ), CM-Mis = Cattle Manure from Miscanthus shredded bedding, CM-WS = Cattle Manure from Wheat Straw shredded bedding, UAN = Urea Ammonium Nitrate).

\begin{tabular}{ccccccc}
\hline Exp. & CS & CS-Mis & $\begin{array}{c}\text { CS-WS } \\
\left.\text { N Immobilisation [kg ha }{ }^{-1}\right]\end{array}$ & CM-WS & UAN \\
\hline 1 & 34 & 60 & 51 & 80 & 15 & 21 \\
2 & 23 & 48 & 25 & 123 & 50 & 40 \\
3 & 26 & 23 & 19 & 46 & -16 & 46 \\
\hline
\end{tabular}




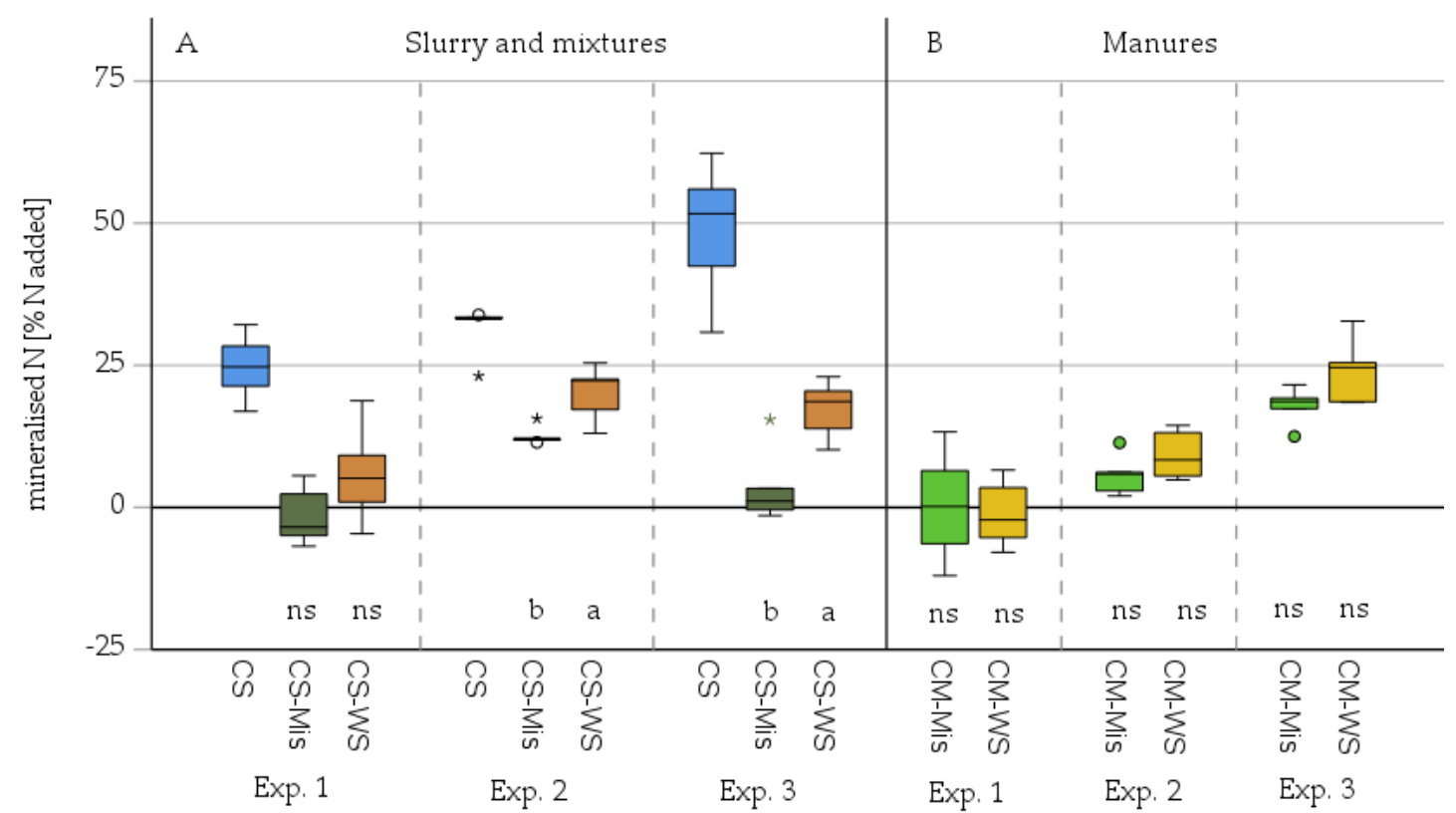

Figure 2. $\mathrm{N}$ mineralised expressed as $\%$ of $\mathrm{N}$ applied for experiment $1\left(120 \mathrm{~kg}\right.$ total $\left.\mathrm{N} \mathrm{ha}^{-1}\right)$ and experiment 2 and 3 $\left(170 \mathrm{~kg}\right.$ total $\left.\mathrm{N} \mathrm{ha}^{-1}\right)$ cumulated until the end of the experiment for each treatment $(\mathbf{A})$ : CS = Cattle Slurry, CS-Mis = Cattle Slurry-Miscanthus (5 kg to $1 \mathrm{~kg}$ ), CS-WS = Cattle Slurry-Wheat Straw (8.5 kg to $1 \mathrm{~kg}$ ); (B): CM-Mis = Cattle Manure from Miscanthus shredded bedding, CM-WS = Cattle Manure from Wheat Straw shredded bedding). The dot indicates a "statistical outlier"; the star indicates an "extreme statistical outlier". Different letters within a column and within each experiment number show significant differences between the two types of mixtures (CS-Mis, CS-WS) and between the two types of manure (CM-Mis, CM-WS) ( $p<0.05, t$-test); ns = not significant; $n=5$.

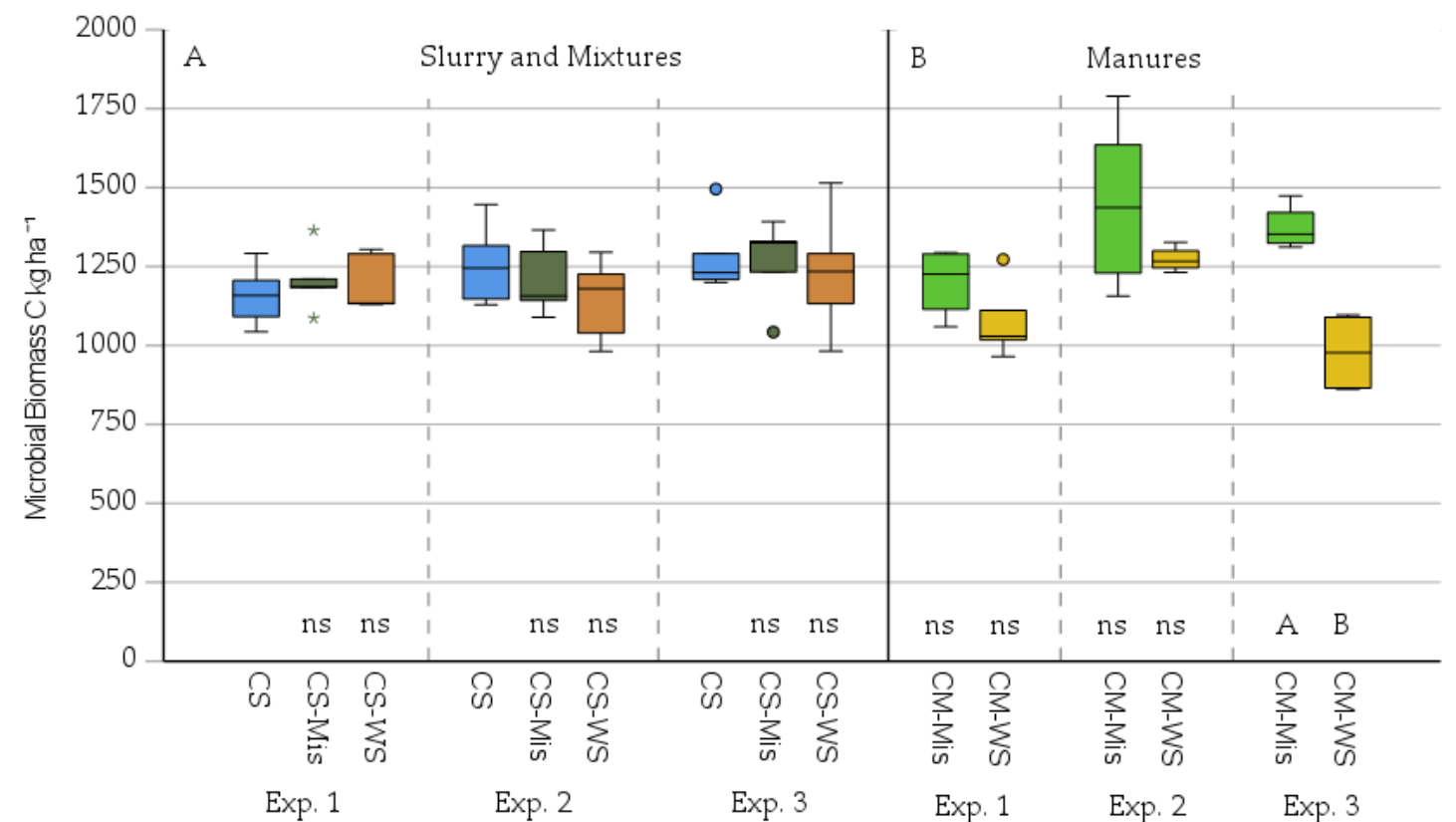

Figure 3. Microbial biomass $\mathrm{C} \mathrm{kg} \mathrm{ha}{ }^{-1}$ of the soils, applied with different organic fertiliser for experiment 1 (120 kg total $\mathrm{N} \mathrm{ha}^{-1}$ ) and exp. 2 and $3\left(170 \mathrm{~kg}\right.$ total $\left.\mathrm{N} \mathrm{ha}^{-1}\right)$ at the end of the experiment for each treatment (A): CS = Cattle Slurry, CS-Mis = Cattle Slurry-Miscanthus (5 kg to $1 \mathrm{~kg}$ ), CS-WS = Cattle Slurry-Wheat Straw (8.5 kg to $1 \mathrm{~kg}$ ); (B): CM-Mis = Cattle Manure from Miscanthus shredded bedding, CM-WS = Cattle Manure from Wheat Straw shredded bedding). The dot indicates a "statistical outlier"; the star indicates an "extreme statistical outlier". Different letters within a column and within each experiment number show significant differences between the two types of mixtures and between the two types of manure $(p<0.05, t$-test $) ; \mathrm{ns}=$ not significant; $n=5$. 


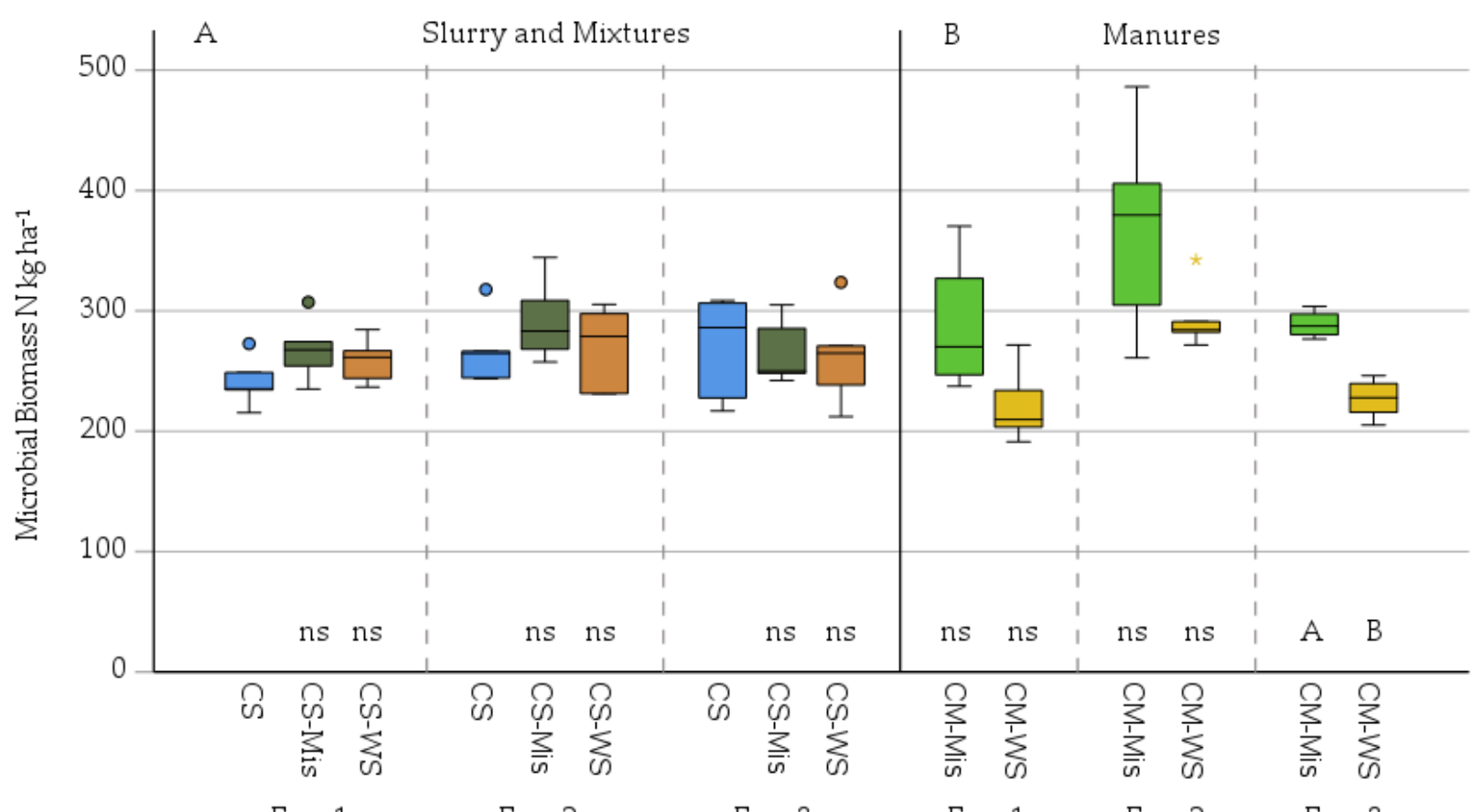

Exp. 1

Exp. 2

Exp. 3

Exp. 1

Exp. 2

Exp. 3

Figure 4. Microbial biomass $\mathrm{N} \mathrm{kg} \mathrm{ha}{ }^{-1}$ of the soils, applied with different organic fertiliser for experiment 1 (120 kg total $\mathrm{N}$ $\left.\mathrm{ha}^{-1}\right)$ and exp. 2 and $3\left(170 \mathrm{~kg}\right.$ total $\left.\mathrm{N} \mathrm{ha}^{-1}\right)$ at the end of the experiment for each treatment (A): CS = Cattle Slurry, CS-Mis = Cattle Slurry-Miscanthus (5 kg to $1 \mathrm{~kg}$ ), CS-WS = Cattle Slurry-Wheat Straw (8.5 kg to $1 \mathrm{~kg}),(\mathbf{B})$ : CM-Mis = Cattle Manure from Miscanthus shredded bedding, CM-WS = Cattle Manure from Wheat Straw shredded bedding). The dot indicates a "statistical outlier"; the star indicates an "extreme statistical outlier". Different letters within a column and within each experiment number show significant differences between the two types of mixtures and between the two types of manure $(p<0.05, t$-test $) ; \mathrm{ns}=$ not significant; $n=5$.

When cattle manure (CM) from Mis as well as from WS were used as organic fertiliser, in exp. 2 and 3, a lower fraction, although not statistically significant, of CM-Mis was mineralized than of CM-WS (Figure 2B). In exp. 1, the same amount of $\mathrm{N}$ was mineralized as became plant available from the soil $\mathrm{N}$ pool in the unfertilized ryegrass. Consequently, no additional $\mathrm{N}$ was mineralised of both $\mathrm{CM}-\mathrm{Mis}$ and $\mathrm{CM}-\mathrm{WS}$ (Figure 2B). The tendency for lower $\mathrm{N}$ mineralization after $\mathrm{CM}-\mathrm{Mis}$ fertilisation compared to CM-WS fertilisation was accompanied by a higher MBN in all experiments. In exp. 1 and 2, the difference was slightly lower, in exp. 3 it was obvious and significant for both, MBN and MBC (Figures 3B and $4 \mathrm{~B}$ ). In CM-Mis, MBN was higher (46 kg ha ${ }^{-1}$ to $123 \mathrm{~kg} \mathrm{ha}^{-1}$ ) and in CM-WS, MBN was mostly higher compared to the non-fertilised treatment (-16 $\mathrm{kg} \mathrm{ha}^{-1}$ to $50 \mathrm{~kg} \mathrm{ha}^{-1}$ ) (Table 9).

After application of UAN and in the treatment without any $\mathrm{N}$ addition (NoN), the MBC did not differ and the MBN predominantly did not differ statistically significantly from the treatment with organic fertilisation (data not shown). MBC was slightly higher after UAN fertilisation (UAN: exp. $1=$ mean $1096 \mathrm{~kg} \mathrm{ha}^{-1} \pm$ SD 104; exp. $2=1269 \mathrm{~kg} \mathrm{ha}^{-1}$ \pm 116 ; exp. $3=1254 \mathrm{~kg} \mathrm{ha}^{-1} \pm 184$ ) than in the non-fertilized treatment (NoN: exp. $1=$ $1024 \mathrm{~kg} \mathrm{ha}^{-1} \pm 117$; exp. $2=1084 \mathrm{~kg} \mathrm{ha}^{-1} \pm 128 ;$ exp. $\left.3=999 \mathrm{~kg} \mathrm{ha}^{-1} \pm 131\right)$. MBN after UAN fertilisation was $229 \mathrm{~kg} \mathrm{ha}^{-1} \pm 29$ in exp. 1, $284 \mathrm{~kg} \mathrm{ha}^{-1} \pm 40$ in exp. 2 and $289 \mathrm{~kg}$ ha $^{-1} \pm 12$ in exp. 3 , showing a slight increase as a result of UAN addition compared to the treatment without $\mathrm{N}$ fertilisation (NoN: exp. $1=207 \mathrm{~kg} \mathrm{ha}^{-1} \pm 35 ;$ exp. $2=244 \mathrm{~kg} \mathrm{ha}^{-1} \pm$ 22; exp. $3=243 \mathrm{~kg} \mathrm{ha}^{-1} \pm 30$ ). 


\section{Discussion}

\subsection{Miscanthus-Induced N Immobilisation}

As an organic C source, we tested the utilisation of Mis and WS concerning N immobilisation and MB build-up which can yield in $C$ sequestration. We demonstrate that Mis is at least as good as WS as a utilizable C source facilitating $\mathrm{N}$ immobilisation and microbial growth eventually contributing to the formation of microbial necromass and thus SOC. Nevertheless, the increase in MB is low, which is mainly caused by the large MB background, as caused by grassland conversion to arable land in 2013, overriding the effects of organic fertilisers. Thus, we expect clearer effects in soils with lower SOM.

The process of microbial $\mathrm{N}$ mineralisation-immobilisation depends on the biochemical composition of the substrate. In general, these processes are characterized by the $\mathrm{NH}_{4}{ }^{+}$ content, the $\mathrm{C} / \mathrm{N}$ ratio and the holocellulose and lignin contents [36,66-68]. For WS, the holocellulose content is estimated to be $68 \%$ to $76 \%$ and the lignin content is estimated to be between $8 \%$ and $25 \%$ [36,69-72]. For Mis, the holocellulose content is given as $70 \%$ and the lignin content as between $14 \%$ to $19 \%$ [71,73], being in the same range as WS. In contrast, the $\mathrm{C} / \mathrm{N}$ ratio of WS was clearly lower at 73 (exp. 1,2) and 115 (exp. 3) compared to that of Mis at 166 (exp. 1,2) and 288 (exp. 3). Additionally, C availability was enhanced by lower mixing ratio of CS-Mis (5:1) compared to CS-WS (8.5:1) (Tables 3 and 4), suggesting a higher microbially available $\mathrm{C}$ derived from CS in the Mis-based fertiliser (CS-Mis, CMMis). In contrast, the $\mathrm{NH}_{4}{ }^{+}$content of both mixtures was almost identical. Thus, the higher microbially available $\mathrm{C}$ input in the form of Mis appears to have caused greater microbial $\mathrm{N}$ immobilisation, especially by the time of the 1st harvest, which is confirmed by a higher MBN in CS-Mis treatment (Figure 4A). The addition of Mis as bedding material also resulted in a higher $\mathrm{C} / \mathrm{N}$ ratio of CM-Mis compared to CM-WS (Tables 3 and 4) and thus also (like CS-Mis already) resulted in lower $\mathrm{N}$ uptake at 1st harvest (Figure 1). For $\mathrm{CM}-\mathrm{Mis}$, we also assume the reason for a stronger $\mathrm{N}$ immobilisation being higher easily available C (as already for CS-Mis) compared to CM-WS. Another influence on the higher $\mathrm{N}$ immobilisation of the Mis treatments and for the MBN tending to be higher, might be the smaller particle size of Mis or a difference in the surface structure as compared to WS, which accelerates and facilitates microbial degradation processes [74]. This, however, needs to be verified in future studies.

Eiland et al. (2001a) [71] and Eiland et al. (2001b) [75] tested the addition of Mis to pig manure to produce a growth medium for plants via composting processes. They reported a clear reduction in nitrification at a $\mathrm{C} / \mathrm{N}$ of 35 compared to a $\mathrm{C} / \mathrm{N}$ of 11 , we observed $\mathrm{N}$ immobilisation at a $\mathrm{C} / \mathrm{N}$ ratio of less than 30 (CS-Mis, CM-Mis). However, the two experimental settings cannot be compared because, unlike Eiland et al. (2001a) [71] and Eiland et al. (2001b) [75], we incorporated our treatments into the soil and there is a likelihood of $\mathrm{NH}_{4}{ }^{+}$released by microorganisms being fixed at negatively charged sites of clay minerals and SOM. Moreover, soil potassium $(\mathrm{K})$ status, $\mathrm{K}^{+}$saturation, moisture conditions and the cation exchange capacity of the soil influence the amount of $\mathrm{NH}_{4}^{+}$ that can be fixed and thus reduce its nitrification and plant availability [76]. Jensen et al. (2001) [77] and Leth et al. (2001) [78] also conducted composting experiments of Mis with pig slurry and other $\mathrm{N}$ sources and observed high microbial activities respectively. Like our experiments, these results indicate a high amount of $\mathrm{C}$ in $\mathrm{Mis}$ that can be easily degraded by microorganisms, provided that a sufficient amount of available $\mathrm{N}$ is accessible.

Some other studies showed promotion of $\mathrm{MB}$ and thus $\mathrm{N}$ immobilisation after Mis biomass incorporation into the soil or application to the soil surface [79-81]. In contrast, Schimmelpfennig et al. (2015) [82], detected no initial N immobilisation after addition of Mis and slurry, successively, possibly because more $\mathrm{N}$ was added than became immobilised. Rex et al., (2015) [83] determined a decrease of fungal biomass, but an increase in bacterial biomass, when Mis biomass and pig slurry were applied together compared to pig slurry alone.

Especially on agricultural fields with a high potential of pedogenic N-mineralization, an additional C-input can reduce the risk for $\mathrm{N}$-losses by induced microbial $\mathrm{N}$-immobilisa- 
tion $[35,36]$, causing $\mathrm{N}$ to be assimilated into the microbial cells and thus decreasing the inorganic N of the soil [74]. Reichel et al., (2018) [35] and Wei et al., (2020) [36] induced $\mathrm{N}$ immobilisation by the application of high carbon amendments, such as wheat straw and spruce sawdust and mention the holocellulose/lignin ratio as a future tool to prevent $\mathrm{N}$ losses. Our experiments, suggesting a tendency for microbial $\mathrm{N}$ immobilisation to be slightly higher when Mis is used compared to WS, each in conjunction with excreta (Figure 1, Table 7), lead us to assume that Mis may find suitability for $\mathrm{N}$ immobilisation even without the addition of excreta as a high carbon amendment for $\mathrm{N}$ immobilisation.

The relative data of $\mathrm{N}$ uptake of the two mixtures (CS-Mis, CS-WS) to N uptake of CS (Table 7) as well as the percentage of $\mathrm{N}$ uptake of the new type of cattle manure from Miscanthus shredded bedding (CM-Mis) to N uptake of conventional cattle manure from wheat straw bedding (CM-WS) (Table 8) demonstrate to the farmer how these fertilisers can be estimated and applied in comparison to the well-known fertilisers.

\subsection{Miscanthus as C Source for Microbial-Derived C Sequestration and SOM Build-Up}

For build-up of SOC, N compounds are essential [30,31]. In many areas, high organic $\mathrm{N}$ amounts are already formed by excretions in animal farming. These have a high potential for humus build-up, which, however, cannot be exploited without sufficient $C$ availability and the humus build-up can only be insufficiently formed, resulting in a higher risk of $\mathrm{N}$ losses instead. In contrast, sufficient $\mathrm{C}$ availability with simultaneous $\mathrm{N}$ supply, as provided by CS-Mis and CM-Mis, could contribute to the formation of microbial necromass. Especially necromass has an essential role in the formation, conservation and stability of SOM and is thus a key component of $\mathrm{C}$ sequestration in soil $[30,31,84,85]$. Thus, the increase of SOM as $\mathrm{C}$ and $\mathrm{N}$ storage improves soil fertility. This would result in a reduction of $\mathrm{N}$ losses and in future could increase the NUE of organic $\mathrm{N}$ fertilisers. Future studies need to verify the role of Mis in microbial necromass formation to better understand its contribution to SOC build-up.

The cultivation of Mis enables farmers to develop an additional $\mathrm{C}$ source regionally [52]. The process of mixing CS with Mis, compared to the cascade utilisation as bedding material, does require an additional working step. However, both options contribute an increase in the SOM by promoting MB [30,31]. The additional source of Mis-C in areas with high livestock numbers and thus high demand for bedding and fodder material in form of cereal straw may also buffer the demand for cereal-based C in arable regions [86], leaving more $\mathrm{C}$ in arable regions to conserve SOC and thus counteract the continuous SOM losses [13]. Additional C production through Mis cultivation also counteracts dependence on external $\mathrm{C}$ sources such as imported organic fertilisers like slurry and farm manure in predominantly arable farming areas. Furthermore, Mis can fulfill and compensate the increasing demand for bedding materials in livestock production [53], which is also a result of societal requests for animal welfare conditions as well as the rising demand for cereal straw as a feed component.

In addition to Mis as an accredited crop of ecological compensation conservation areas [48], other greening measures, such as hedges or trees in agroforestry systems also provide an alternative $\mathrm{C}$ source that could be used for induced $\mathrm{N}$ immobilisation and SOC build-up. Removal of vegetation material from buffer strips, erosion strips and riparian strips as $\mathrm{C}$-source would result in nutrient removal and thus nutrient reduction of the greening part, which benefits biodiversity at these sites. This would be a positive development regarding nature conservation (increase of plant diversity, habitat for insects and other animals). The useful utilisation as a C-source could ensure the removal of mown material, but requires tests concerning the effectiveness on $\mathrm{N}$ immobilisation and the effects on the MB.

If organic $\mathrm{N}$-fertilisers containing $\mathrm{Mis}$ are applied, where $\mathrm{N}$ is directly required, yield deficits due to microbial $\mathrm{N}$ immobilisation are to be expected, if they are applied exclusively. In this case, the $\mathrm{N}$ demand can be supplied by the application of additional ready available $\mathrm{N}$ fertilisers and the residual effects can be included in subsequent vegetation periods, as is 
also common practice with the application of other organic fertilisers [42]. An estimation of the amount of accounting for subsequent growing seasons is not possible due to missing data from field trials. Earlier application of organic farm manures in the winter months in order to expect higher $\mathrm{N}$ mineralisation in spring is also not recommended due to missing data from field trials and due to the risk of $\mathrm{N}$ losses to ecosystems.

\section{Conclusions}

The specific characteristics of Miscanthus (Mis), such as the higher $\mathrm{C} / \mathrm{N}$ ratio compared to WS, were reflected in a slightly higher $\mathrm{N}$ immobilisation. Especially at the 1st and 2nd harvest, CS-Mis and CM-Mis were partly significantly different from the comparative treatments CS-WS and CM-WS. The Mis-C resulted in a slightly higher MBC and MBN and thus can contribute as an additional $\mathrm{C}$ source to prevent $\mathrm{N}$ losses and for the maintenance or build-up of SOM on agricultural farms. We assume that high background values of $\mathrm{SOM}$ and thus a high starting content of $\mathrm{MB}$, as caused by grassland conversion to arable land, overrode the effects.

Author Contributions: Conceptualization, M.S., F.W., R.P. and M.H.; methodology, M.S.; software, M.S.; validation, M.S.; formal analysis, M.S.; investigation, M.S.; resources, F.W., R.P. and M.H.; data curation, M.S.; writing—original draft preparation, M.S.; writing—review and editing, M.S., F.W., R.P. and M.H.; visualization, M.S.; supervision, F.W., R.P. and M.H.; project administration, F.W., R.P. and M.H.; funding acquisition, M.H. All authors have read and agreed to the published version of the manuscript.

Funding: The research was carried out within the framework of the INTERREG V A program Germany-Netherland-Co-financed by the European Regional Development Fund (ERDF) and the Dutch Ministry of Economic Affairs, MWIDE NRW and the provinces of Gelderland, Limburg and Noord-Brabant.

Institutional Review Board Statement: Not applicable.

Informed Consent Statement: Not applicable.

Data Availability Statement: The data presented in this study are available on request from the corresponding author.

Acknowledgments: We thank the team of Faculty of Life Sciences, the team of International Centre for Sustainable Development and the team of Campus Klein-Altendorf, especially Kevin Leitenberger, for support in the experimental work. Further, we are grateful to the analytical support by Angelika Glogau, Waltraud Köhler and Conor Watson.

Conflicts of Interest: The authors declare no conflict of interest. The funders had no role in the design of the study; in the collection, analyses, or interpretation of data; in the writing of the manuscript, or in the decision to publish the results.

\section{References}

1. Tilman, D.; Cassman, K.G.; Matson, P.A.; Naylor, R.; Polasky, S. Agricultural sustainability and intensive production practices. Nature 2002, 418, 671-677. [CrossRef] [PubMed]

2. Bouwman, L.; Goldewijk, K.K.; Van Der Hoek, K.W.; Beusen, A.; van Vuuren, D.; Willems, J.; Rufino, M.; Stehfest, E. Exploring global changes in nitrogen and phosphorus cycles in agriculture induced by livestock production over the 1900-2050 period. Proc. Natl. Acad. Sci. USA 2013, 110, 20882-20887. [CrossRef] [PubMed]

3. Naylor, R.L. Energy and Resource Constraints on Intensive Agricultural Production. Annu. Rev. Energy Environ. 1996, 21, 99-123. [CrossRef]

4. Cassman, K.G. Ecological intensification of cereal production systems: Yield potential, soil quality, and precision agriculture. Proc. Natl. Acad. Sci. USA 1999, 96, 5952-5959. [CrossRef]

5. Smil, V. Nitrogen in crop production: An account of global flows. Glob. Biogeochem. Cycles 1999, 13, 647-662. [CrossRef]

6. Cassman, K.G.; Dobermann, A.; Walters, D.T. Agroecosystems, Nitrogen-use Efficiency, and Nitrogen Management. AMBIO 2002, 31, 132-140. [CrossRef]

7. Galloway, J.N.; Dentener, F.J.; Capone, D.G.; Boyer, E.W.; Howarth, R.W.; Seitzinger, S.P.; Asner, G.P.; Cleveland, C.C.; Green, P.A.; Holland, E.A.; et al. Nitrogen Cycles: Past, Present, and Future. Biogeochemistry 2004, 70, 153-226. [CrossRef] 
8. Sandel, B.; Arge, L.; Dalsgaard, B.; Davies, R.G.; Gaston, K.J.; Sutherland, W.; Svenning, J.-C. The Influence of Late Quaternary Climate-Change Velocity on Species Endemism. Science 2011, 334, 660-664. [CrossRef]

9. Goidts, E.; van Wesemael, B. Regional assessment of soil organic carbon changes under agriculture in Southern Belgium (1955-2005). Geoderma 2007, 141, 341-354. [CrossRef]

10. Sleutel, S.; De Neve, S.; Hofman, G. Assessing causes of recent organic carbon losses from cropland soils by means of regionalscaled input balances for the case of Flanders (Belgium). Nutr. Cycl. Agroecosyst. 2007, 78, 265-278. [CrossRef]

11. Meersmans, J.; van Wesemael, B.; Goidts, E.; Van Molle, M.; De Baets, S.; De Ridder, F. Spatial analysis of soil organic carbon evolution in Belgian croplands and grasslands, 1960-2006. Glob. Chang. Biol. 2010, 17, 466-479. [CrossRef]

12. Steinmann, T.; Welp, G.; Holbeck, B.; Amelung, W. Long-term development of organic carbon contents in arable soil of North Rhine-Westphalia, Germany, 1979-2015. Eur. J. Soil Sci. 2016, 67, 616-623. [CrossRef]

13. Steinmann, T.; Welp, G.; Wolf, A.; Holbeck, B.; Amelung, W.; Große-Rüschkamp, T. Repeated monitoring of organic carbon stocks after eight years reveals carbon losses from intensively managed agricultural soils in Western Germany. J. Plant Nutr. Soil Sci. 2016, 179, 355-366. [CrossRef]

14. Bellamy, P.; Loveland, P.J.; Bradley, R.I.; Lark, R.; Kirk, G. Carbon losses from all soils across England and Wales 1978-2003. Nat. Cell Biol. 2005, 437, 245-248. [CrossRef]

15. Geisseler, D.; Horwath, W.R.; Joergensen, R.G.; Ludwig, B. Pathways of nitrogen utilization by soil microorganisms-A review. Soil Biol. Biochem. 2010, 42, 2058-2067. [CrossRef]

16. Geisseler, D.; Horwath, W.R. Investigating amino acid utilization by soil microorganisms using compound specific stable isotope analysis. Soil Biol. Biochem. 2014, 74, 100-105. [CrossRef]

17. Joergensen, R.; Wichern, F. Quantitative assessment of the fungal contribution to microbial tissue in soil. Soil Biol. Biochem. 2008, 40, 2977-2991. [CrossRef]

18. Dilly, O.; Blume, H.-P.; Munch, J.C. Soil microbial activities in Luvisols and Anthrosols during 9 years of region-typical tillage and fertilisation practices in northern Germany. Biogeochemistry 2003, 65, 319-339. [CrossRef]

19. Joergensen, R.G.; Emmerling, C. Methods for evaluating human impact on soil microorganisms based on their activity, biomass, and diversity in agricultural soils. J. Plant Nutr. Soil Sci. 2006, 169, 295-309. [CrossRef]

20. Sørensen, P. Immobilisation, remineralisation and residual effects in subsequent crops of dairy cattle slurry nitrogen compared to mineral fertiliser nitrogen. Plant Soil 2004, 267, 285-296. [CrossRef]

21. Daudén, A.; Quilez, D.; Martínez, C. Residual effects of pig slurry applied to a Mediterranean soil on yield and N uptake of a subsequent wheat crop. Soil Use Manag. 2004, 20, 156-162. [CrossRef]

22. Sørensen, P.; Thomsen, I.K. Separation of Pig Slurry and Plant Utilization and Loss of Nitrogen-15-labeled Slurry Nitrogen. Soil Sci. Soc. Am. J. 2005, 69, 1644-1651. [CrossRef]

23. Spiertz, J.H.J. Nitrogen, Sustainable Agriculture and Food Security: A Review. In Sustainable Agriculture; Lichtfouse, E., Navarrete, M., Debaeke, P., Véronique, S., Alberola, C., Eds.; Springer: Dordrecht, The Netherlands, 2009; pp. 635-651. ISBN 9789048126651.

24. Richards, J.E.; Webster, C.P. Denitrification in the subsoil of the Broadbalk Continuous Wheat Experiment. Soil Biol. Biochem. 1999, 31, 747-755. [CrossRef]

25. Lal, R. World cropland soils as a source or sink for atmospheric carbon. Adv. Agron. 2001, 71, 145-191. [CrossRef]

26. Poissant, L.; Beauvais, C.; Lafrance, P.; Deblois, C. Pesticides in fluvial wetlands catchments under intensive agricultural activities. Sci. Total. Environ. 2008, 404, 182-195. [CrossRef] [PubMed]

27. Ilumäe, E.; Akk, E.; Hansson, A.; Kastanje, V. Changes the content of organic matter in soil during the whole cycle of crop rotation. Agronomy 2009, 7, 263-268.

28. Smith, P. How long before a change in soil organic carbon can be detected? Glob. Chang. Biol. 2004, 10, 1878-1883. [CrossRef]

29. Powlson, D.; Prookes, P.; Christensen, B. Measurement of soil microbial biomass provides an early indication of changes in total soil organic matter due to straw incorporation. Soil Biol. Biochem. 1987, 19, 159-164. [CrossRef]

30. Kallenbach, C.M.; Frey, S.D.; Grandy, A.S. Direct evidence for microbial-derived soil organic matter formation and its ecophysiological controls. Nat. Commun. 2016, 7, 13630. [CrossRef]

31. Khan, K.S.; Mack, R.; Castillo, X.; Kaiser, M.; Joergensen, R.G. Microbial biomass, fungal and bacterial residues, and their relationships to the soil organic matter C/N/P/S ratios. Geoderma 2016, 271, 115-123. [CrossRef]

32. Joergensen, R.G.; Mueller, T. The fumigation-extraction method to estimate soil microbial biomass: Calibration of the kEN value. Soil Biol. Biochem. 1996, 28, 33-37. [CrossRef]

33. Chen, B.; Liu, E.; Tian, Q.; Yan, C.; Zhang, Y. Soil nitrogen dynamics and crop residues. A review. Agron. Sustain. Dev. 2014, 34, 429-442. [CrossRef]

34. Abbasi, M.K.; Tahir, M.M.; Sabir, N.; Khurshid, M. Impact of the addition of different plant residues on nitrogen mineralizationimmobilization turnover and carbon content of a soil incubated under laboratory conditions. Solid Earth 2015, 6, 197-205. [CrossRef]

35. Reichel, R.; Wei, J.; Islam, M.S.; Schmid, C.; Wissel, H.; Schröder, P.; Schloter, M.; Bruggemann, N. Potential of Wheat Straw, Spruce Sawdust, and Lignin as High Organic Carbon Soil Amendments to Improve Agricultural Nitrogen Retention Capacity: An Incubation Study. Front. Plant Sci. 2018, 9, 900. [CrossRef] [PubMed] 
36. Wei, J.; Reichel, R.; Islam, M.S.; Wissel, H.; Amelung, W.; Brüggemann, N. Chemical Composition of High Organic Carbon Soil Amendments Affects Fertilizer-Derived N2O Emission and Nitrogen Immobilization in an Oxic Sandy Loam. Front. Environ. Sci. 2020, 8, 115. [CrossRef]

37. Nishio, T.; Oka, N. Effect of Organic matter application on the fate of15N-labeled ammonium fertilizer in an upland soil. Soil Sci. Plant Nutr. 2003, 49, 397-403. [CrossRef]

38. Shindo, H.; Nishio, T. Immobilization and remineralization of $\mathrm{N}$ following addition of wheat straw into soil: Determination of gross $\mathrm{N}$ transformation rates by $15 \mathrm{~N}$-ammonium isotope dilution technique. Soil Biol. Biochem. 2005, 37, 425-432. [CrossRef]

39. Simon, T.; Kunzová, E.; Friedlová, M. The effect of digestate, cattle slurry and mineral fertilization on the winter wheat yield and soil quality parameters. Plant Soil Environ. 2016, 61, 522-527. [CrossRef]

40. García-Ruiz, R.; Carranza-Gallego, G.; Aguilera, E.; De Molina, M.G.; Guzmán, G.I. C and N mineralisation of straw of traditional and modern wheat varieties in soils of contrasting fertility. Nutr. Cycl. Agroecosyst. 2019, 113, 167-179. [CrossRef]

41. Joergensen, R.G.; Wichern, F. Alive and kicking: Why dormant soil microorganisms matter. Soil Biol. Biochem. 2018, 116, 419-430. [CrossRef]

42. Schröder, J.J. The Position of Mineral Nitrogen Fertilizer in Efficient Use of Nitrogen and Land: A Review. Nat. Resour. 2014, 05, 936-948. [CrossRef]

43. Blagodatsky, S.; Richter, O. Microbial growth in soil and nitrogen turnover: A theoretical model considering the activity state of microorganisms. Soil Biol. Biochem. 1998, 30, 1743-1755. [CrossRef]

44. Schulten, H.-R.; Schnitzer, M. The chemistry of soil organic nitrogen: A review. Biol. Fertil. Soils 1997, 26, 1-15. [CrossRef]

45. Lutzow, M.V.; Kögel-Knabner, I.; Ekschmitt, K.; Matzner, E.; Guggenberger, G.; Marschner, B.; Flessa, H. Stabilization of organic matter in temperate soils: Mechanisms and their relevance under different soil conditions-a review. Eur. J. Soil Sci. 2006, 57, 426-445. [CrossRef]

46. Olk, D.; Cassman, K.; Schmidt-Rohr, K.; Anders, M.; Mao, J.-D.; Deenik, J. Chemical stabilization of soil organic nitrogen by phenolic lignin residues in anaerobic agroecosystems. Soil Biol. Biochem. 2006, 38, 3303-3312. [CrossRef]

47. Emmerling, C.; Pude, R. Introducing Miscanthus to the greening measures of the EU Common Agricultural Policy. GCB Bioenergy 2016, 9, 274-279. [CrossRef]

48. European Union. Regulation (EU) No. 2017/2393 of the european parliament and of the council-of 13 December 2017-amending Regulations (EU) No 1305/2013 on support for rural development by the European Agricultural Fund for Rural Development (EAFRD), (EU) No 1306/2013 on the financing, management and monitoring of the common agricultural policy, (EU) No $1307 / 2013$ establishing rules for direct payments to farmers under support schemes within the framework of the common agricultural policy, (EU) No 1308/2013 establishing a common organisation of the markets in agricultural products and (EU) No 652/2014 laying down provisions for the management of expenditure relating to the food chain, animal health and animal welfare, and relating to plant health and plant reproductive material. Off. J. Eur. Union 2017, 15-49.

49. Ruf, T.; Emmerling, C. Impact of premature harvest of Miscanthus x giganteus for biogas production on organic residues, microbial parameters and earthworm community in soil. Appl. Soil Ecol. 2017, 114, 74-81. [CrossRef]

50. Schmidt, A.; Lemaigre, S.; Ruf, T.; Delfosse, P.; Emmerling, C. Miscanthus as biogas feedstock: Influence of harvest time and stand age on the biochemical methane potential (BMP) of two different growing seasons. Biomass-Convers. Biorefinery 2017, 8 , 245-254. [CrossRef]

51. Nguyen, V.; Elfers, J.; Kühn, H.; Kraska, T.; Pude, R. Different Miscanthus genotypes as growing media in soilless tomato cultivation and its subsequent use for combustion. Acta Hortic. 2021, 301-308. [CrossRef]

52. Pude, R. Nachwachsende Rohstoffe aus der Region und für die Region. Berichte über Landwirtschaft-Zeitschrift für Agrarpolitik und Landwirtschaft Aktuelle Beiträge 2021, 99, 1-12. [CrossRef]

53. Van Weyenberg, S.; Ulens, T.; De Reu, K.; Zwertvaegher, I.; Demeyer, P.; Pluym, L. Feasibility of Miscanthus as alternative bedding for dairy cows. Vet. Med. 2016, 60, 121-132. [CrossRef]

54. Wilke, B.-M. Determination of Chemical and Physical Soil Properties. In Manual for Soil Analysis: Monitoring and Assessing Soil Bioremediation; Margesin, R., Schinner, F., Eds.; Springer: Berlin/Heidelberg, Germany, 2005; pp. 47-95. ISBN 3540253467.

55. ISO; DIN. Bodenbeschaffenheit-Bestimmung der Partikelgrößenverteilung in Mineralböden-Verfahren Mittels Siebung und Sedimentation; Deutsches Institut für Normung e. V.: Berlin, Germany, 2002; p. 11277.

56. VDLUFA. Methode A 5.1.1. Bestimmung des pH-Wertes. In Methodenbuch I Die Untersuchung von Böden; VDLUFA-Verlag: Darmstadt, Germany, 2016.

57. VDLUFA. Methode A 6.2.1.1. Bestimmung von Phosphor und Kalium im Calcium-Acetat-Lactat-Auszug. In Methodenbuch I Die Untersuchung von Böden; VDLUFA-Verlag: Darmstadt, Germany, 2012.

58. VDLUFA. Methode A 6.2.4.1 Bestimmung des pflanzenverfügbaren Magnesiums im Calciumchlorid-Auszug. In Methodenbuch I Die Untersuchung von Böden; VDLUFA-Verlag: Darmstadt, Germany, 1997.

59. VDLUFA. Methode A 6.4.1. Bestimmung von Magnesium, Natrium, und den Spurennährstoffen Kupfer, Mangan, Zink und Bor im Calciumchlorid/DTPA-Auszug. In Methodenbuch I Die Untersuchung von Böden; VDLUFA-Verlag: Darmstadt, Germany, 2002.

60. ISO; DIN. Bodenbeschaffenheit-Bestimmung von Organischem Kohlenstoff und Gesamtkohlenstoff Nach Trockener Verbrennung (Elementaranalyse); Deutsches Institut für Normung e. V.: Berlin, Germany, 1996; p. 10694.

61. ISO; DIN. Bodenbeschaffenheit-Bestimmung des Gesamt-Stickstoffs Durch Trockene Verbrennung (Elementaranalyse); Deutsches Institut für Normung e. V.: Berlin, Germany, 1998; p. 13878. 
62. Bundesministerium der Justiz und für Verbraucherschutz. Düngeverordnung 2017; BGBl: Berlin, Germany, 2017 ; pp. 1305-1348.

63. Brookes, P.; Landman, A.; Pruden, G.; Jenkinson, D. Chloroform fumigation and the release of soil nitrogen: A rapid direct extraction method to measure microbial biomass nitrogen in soil. Soil Biol. Biochem. 1985, 17, 837-842. [CrossRef]

64. Vance, E.; Brookes, P.; Jenkinson, D. Microbial biomass measurements in forest soils: Determination of $\mathrm{kC}$ values and tests of hypotheses to explain the failure of the chloroform fumigation-incubation method in acid soils. Soil Biol. Biochem. 1987, 19, 689-696. [CrossRef]

65. Wu, J.; Joergensen, R.; Pommerening, B.; Chaussod, R.; Brookes, P. Measurement of soil microbial biomass C by fumigationextraction-an automated procedure. Soil Biol. Biochem. 1990, 22, 1167-1169. [CrossRef]

66. Cabrera, M.L.; Kissel, D.E.; Vigil, M.F. Nitrogen Mineralization from Organic Residues. J. Environ. Qual. 2005, 34, 75-79. [CrossRef] [PubMed]

67. Dittmar, T.; Stubbins, A. Dissolved organic matter in aquatic systems. In Treatise on Geochemistry; Elsevier: Amsterdam, The Netherlands, 2014; pp. 125-156. ISBN 9780080983004.

68. Bhogal, A.; Williams, J.R.; Nicholson, F.A.; Chadwick, D.R.; Chambers, K.H.; Chambers, B.J. Mineralization of organic nitrogen from farm manure applications. Soil Use Manag. 2016, 32, 32-43. [CrossRef]

69. Rahn, C.R.; Bending, G.; Lillywhite, R.D.; Turner, M.K. Chemical characterisation of vegetable and arable crop residue materials: A comparison of methods. J. Sci. Food Agric. 1999, 79, 1715-1721. [CrossRef]

70. Corbeels, M.; Hofman, G.; Van Cleemput, O. Nitrogen cycling associated with the decomposition of sunflower stalks and wheat straw in a Vertisol. Plant Soil 2000, 218/2, 71-82. [CrossRef]

71. Eiland, F.; Leth, M.; Klamer, M.; Lind, A.-M.; Jensen, H.; Iversen, J. C and N Turnover and Lignocellulose Degradation During Composting of Miscanthus Straw And Liquid Pig Manure. Compos. Sci. Util. 2001, 9, 186-196. [CrossRef]

72. Van Kuijk, S.J.; Sonnenberg, A.S.; Baars, J.J.; Hendriks, W.H.; del Río, J.C.; Rencoret, J.; Gutiérrez, A.; De Ruijter, N.; Cone, J.W. Chemical changes and increased degradability of wheat straw and oak wood chips treated with the white rot fungi Ceriporiopsis subvermispora and Lentinula edodes. Biomass-Bioenergy 2017, 105, 381-391. [CrossRef]

73. Pude, R.; Treseler, C.-H.; Trettin, R.; Noga, G. Suitability of Miscanthus Genotypes for Lightweight Concrete. Die Bodenkultur 2005, $56,61-69$.

74. Congreves, K.A.; Vyn, R.J.; Van Eerd, L.L. Evaluation of Post-Harvest Organic Carbon Amendments as a Strategy to Minimize Nitrogen Losses in Cole Crop Production. Agronomy 2013, 3, 181-199. [CrossRef]

75. Eiland, F.; Klamer, M.; Lind, A.-M.; Leth, M.; Bååth, E. Influence of Initial C/N Ratio on Chemical and Microbial Composition during Long Term Composting of Straw. Microb. Ecol. 2001, 41, 272-280. [CrossRef] [PubMed]

76. Nieder, R.; Benbi, D.K.; Scherer, H.W. Fixation and defixation of ammonium in soils: A review. Biol. Fertil. Soils 2011, 47, 1-14. [CrossRef]

77. Jensen, H.E.K.; Leth, M.; Iversen, J.J.L. Growth of Hedera helix L. Container Plants in Compost Substrates Made with Miscanthus ogiformis Honda Straw and Various N-Sources. Compos. Sci. Util. 2001, 9, 206-214. [CrossRef]

78. Leth, M.; Jensen, H.; Iversen, J. Influence of Different Nitrogen Sources on Composting Of Miscanthus in Open and Closed Systems. Compos. Sci. Util. 2001, 9, 197-205. [CrossRef]

79. Beuch, S.; Belau, L.; Boelcke, B. Modelluntersuchungen zur Mineralisierung der Biomasse von Miscanthus x giganteus (Mineralisierung von Miscanthusbiomasse). Arch. Agron. Soil Sci. 1998, 42, 347-357. [CrossRef]

80. Mierzwa-Hersztek, M.; Gondek, K.; Klimkowicz-Pawlas, A.; Baran, A. Effect of wheat and Miscanthus straw biochars on soil enzymatic activity, ecotoxicity, and plant yield. Int. Agrophys. 2017, 31, 367-375. [CrossRef]

81. O'Toole, A.; Moni, C.; Weldon, S.; Schols, A.; Carnol, M.; Bosman, B.; Rasse, D.P. Miscanthus Biochar had Limited Effects on Soil Physical Properties, Microbial Biomass, and Grain Yield in a Four-Year Field Experiment in Norway. Agriculture $2018,8,171$. [CrossRef]

82. Schimmelpfennig, S.; Kammann, C.; Moser, G.; Grünhage, L.; Muller, C. Changes in macro- and micronutrient contents of grasses and forbs following Miscanthus x giganteus feedstock, hydrochar and biochar application to temperate grassland. Grass Forage Sci. 2015, 70, 582-599. [CrossRef]

83. Rex, D.; Schimmelpfennig, S.; Jansen-Willems, A.; Moser, G.; Kammann, C.; Muller, C. Microbial community shifts 2.6 years after top dressing of Miscanthus biochar, hydrochar and feedstock on a temperate grassland site. Plant Soil 2015, 397, 261-271. [CrossRef]

84. Liangguang, C.; Cheng, G.; Wixon, D.L.; Balser, T.C. An Absorbing Markov Chain approach to understanding the microbial role in soil carbon stabilization. Biogeochemistry 2010, 106, 303-309. [CrossRef]

85. Hobara, S.; Osono, T.; Hirose, D.; Noro, K.; Hirota, M.; Benner, R. The roles of microorganisms in litter decomposition and soil formation. Biogeochemistry 2013, 118, 471-486. [CrossRef]

86. Yesufu, J.; McCalmont, J.P.; Clifton-Brown, J.C.; Williams, P.; Hyland, J.; Gibbons, J.; Styles, D. Consequential life cycle assessment of miscanthus livestock bedding, diverting straw to bioelectricity generation. GCB Bioenergy 2019, 12, 39-53. [CrossRef] 